OPEN ACCESS

Edited by:

Angélica Santiago Gómez, The University of Manchester,

United Kingdom

Reviewed by:

Niall Byrme,

Queen's University Belfast,

United Kingdom

Thomas Rosol,

Ohio University, United States

*Correspondence:

Rachelle W. Johnson

rachelle.johnson@vumc.org

Specialty section:

This article was submitted to Molecular and Cellular Oncology,

a section of the journa

Frontiers in Oncology

Received: 20 December 2020 Accepted: 22 February 2021

Published: 22 March 2021

Citation:

Edwards CM and Johnson RW (2021)

From Good to Bad: The Opposing

Effects of PTHrP on Tumor Growth

Dormancy, and Metastasis

Throughout Cancer Progression.

Front. Oncol. 11:644303.

doi: 10.3389/fonc. 2021.644303

\section{From Good to Bad: The Opposing Effects of PTHrP on Tumor Growth, Dormancy, and Metastasis Throughout Cancer Progression}

\author{
Courtney M. Edwards ${ }^{1,2}$ and Rachelle W. Johnson ${ }^{1,2,3 *}$ \\ ${ }^{1}$ Program in Cancer Biology, Vanderbilt University, Nashville, TN, United States, ${ }^{2}$ Vanderbilt Center for Bone Biology, Division \\ of Clinical Pharmacology, Department of Medicine, Vanderbilt University Medical Center, Nashville, TN, United States, \\ ${ }^{3}$ Division of Clinical Pharmacology, Department of Medicine, Vanderbilt University Medical Center, Nashville, TN, \\ United States
}

Parathyroid hormone related protein (PTHrP) is a multifaceted protein with several biologically active domains that regulate its many roles in normal physiology and human disease. PTHrP causes humoral hypercalcemia of malignancy $(\mathrm{HHM})$ through its endocrine actions and tumor-induced bone destruction through its paracrine actions. PTHrP has more recently been investigated as a regulator of tumor dormancy owing to its roles in regulating tumor cell proliferation, apoptosis, and survival through autocrine/paracrine and intracrine signaling. Tumor expression of PTHrP in late stages of cancer progression has been shown to promote distant metastasis formation, especially in bone by promoting tumor-induced osteolysis and exit from dormancy. In contrast, PTHrP may protect against further tumor progression and improve patient survival in early disease stages. This review highlights current knowledge from preclinical and clinical studies examining the role of PTHrP in promoting tumor progression as well as skeletal and soft tissue metastasis, especially with regards to the protein as a regulator of tumor dormancy. The discussion will also provide perspectives on PTHrP as a prognostic factor and therapeutic target to inhibit tumor progression, prevent tumor recurrence, and improve patient survival.

Keywords: PTHrP, bone metastasis, dormancy, hypoxia, proliferation

\section{INTRODUCTION}

The initial discovery of parathyroid hormone- related protein (PTHrP) came about from studies on humoral hypercalcemia of malignancy (HHM), a paraneoplastic syndrome in which elevated levels of PTHrP lead to increased osteoclastic bone resorption and serum calcium levels $(1,2)$. HHM is most commonly diagnosed in patients with advanced-stage lung, renal, and neuroendocrine tumors. Though less frequently, breast cancers can also cause HHM. While hypercalcemia had been associated with cancer since the early twentieth century (3), it was Fuller Albright in 1941 who first postulated that this complication may be caused by tumor secretion of parathyroid hormone (PTH) or another similar factor due to its known roles in calcium homeostasis (4). While functionally this hypothesis seemed likely, clinically this did not prove to be true based on differences in the 
clinical presentation of patients with hypercalcemia due to cancer vs. those with hypercalcemia due to known PTH excess syndromes like primary hyperparathyroidism (5). By the 1980s multiple independent groups had eventually purified a protein similar in structure and biological function to PTH from human lung cancer (6), breast cancer (7), and renal cell carcinoma cell lines (8). This $18 \mathrm{kDA}$ protein, now termed PTHrP, was found to have very high homology with the amino-terminal region of PTH such that eight of the first 13 residues are identical (9).

The role of PTHrP in cancer now extends well beyond its role in HHM. PTHrP is a well-established critical mediator of tumor-induced osteolysis, especially in breast cancer, which has a high tropism for disseminating to the bone marrow. In fact, $\sim 70 \%$ of patients who succumb to breast cancer display evidence of bone metastases on postmortem examination (10). Lung cancer, melanoma, renal cell carcinoma, and thyroid cancers also metastasize to bone with relatively high ( $>20 \%)$ frequency (11) and form osteolytic lesions (12). Bone-disseminated tumor cells secrete PTHrP (13-15), which drives bone destruction via stimulation of receptor activator of NFKB ligand (RANKL)mediated differentiation and activation of osteoclasts (16). Osteoclasts resorb the bone matrix, releasing numerous protumorigenic factors such as transforming growth factor beta (TGF $\beta$ ), matrix metalloproteinases, and other growth factors that subsequently fuel tumor cell proliferation and more PTHrP secretion $(17,18)$. PTHrP expression by bone-disseminated tumor cells is also uniquely fueled by the microenvironment. The rigidity of the bone matrix activates TGF- $\beta$ dependent mechanical signals that stimulate expression of both PTHrP and Gli2, a transcription factor in the hedgehog signaling pathway that in turn induces more PTHrP expression (19). The bone microenvironment provides yet another critical level of regulation of Gli2 and PTHrP expression via the Wnt pathway (20). Matrix rigidity activates Wnt signaling and induces nuclear $\beta$-catenin accumulation, while bone marrow stromal cells secrete canonical (including Wnt3a) and non-canonical Wnt ligands. Both processes further drive Gli2 and PTHrP transcription and eventual bone destruction.

Patients who develop bone metastases may experience severe pain, impaired mobility, pathologic fractures, spinal cord compression and hypercalcemia (21). While bisphosphonates and denosumab, inhibitors of osteoclast activity, are commonly utilized to manage metastasis-related symptoms and have been shown to decrease the incidence of bone metastases, they only improve survival in postmenopausal breast cancer patients $(22,23)$. No survival benefits have been observed in patients who were premenopausal at the time of diagnosis (24-26). Thus, there remains an urgent need to identify therapies that effectively target bone metastatic tumors and improve survival.

In addition to its critical role in tumor-induced bone disease, PTHrP has more recently been investigated as a potential regulator of tumor dormancy owing to its roles in regulating tumor cell proliferation, apoptosis, and survival (27) and genes that have been specifically implicated in tumor dormancy (28). Generally, dormancy can be characterized as (i) cellular dormancy where tumor cells persist as either solitary cells that are non-proliferative (e.g., Ki67 or BrdU negative) and arrested in the G0 cell cycle phase, or (ii) tumor mass dormancy where the growth capacity of micrometastases is limited due to balanced proliferation and apoptosis, suppression of angiogenesis, or immune clearance (29-31). Tumor dormancy is believed to be the cause of late recurrence even months to years following successful removal of the primary tumor (32-34). Long latency periods are mostly frequently observed in estrogen-receptor positive $\left(\mathrm{ER}^{+}\right)$breast cancer $(35,36)$ as well as prostate cancer (37). Patients with other cancer types including non-small cell lung cancer (38), renal cell carcinoma (39) and colorectal cancer (40) may also exhibit late tumor recurrence, although this occurs less frequently than in breast cancer patients. Dramatic increases in breast cancer patient survival in recent decades are, in part, due to significant improvements in treating and managing primary breast tumors. Thus, it is possible that as therapies continue to improve for other cancer types that extend patient survival, longer latency periods may also be observed. Tumor dormancy presents a significant clinical dilemma as these dormant DTCs not only have the potential to become reactivated and proliferate into a macrometastasis, but also evade immune surveillance and anticancer therapy (41, 42). Currently there are no cures for metastatic disease or therapies to prevent tumor exit from dormancy and late recurrence. This review will explore current knowledge from preclinical and clinical studies regarding the role of PTHrP in promoting skeletal and soft tissue metastasis. We will also explore findings regarding $\mathrm{PTHrP}$ as a regulator of tumor dormancy and provide our perspective on PTHrP as a therapeutic target to inhibit tumorigenesis, prevent tumor recurrence, and improve patient survival.

\section{PTHrP BIOLOGY}

PTHLH, the gene encoding PTHrP, is located on chromosome 12, and has nine exons spanning $\sim 15 \mathrm{~kb}$ with at least three identified promoters. Alternative splicing gives rise to three isoforms containing 139, 141, and 173 amino acids (43). PTHrP also has multiple domains, each with different biological functions (44). The first 36 amino acids $(-36$ to -1$)$ encode a domain that controls intracellular trafficking of PTHrP precursors before being cleaved when the mature molecule is secreted. The next domain (amino acids 1-34) is responsible for PTHrP binding to and activation of the PTH receptor type 1 (PTH1R), a Gprotein coupled receptor. In fact, eight of the first 13 residues within this region of PTHrP are identical with PTH, allowing the two polypeptides to exert agonist effects on their shared receptor $(44,45)$. The nuclear localization sequence (NLS) from amino acids 67-94 is important for intracrine actions of PTHrP in the nucleus and cytoplasm including regulating cell proliferation, survival, and apoptosis (46). Lastly, the carboxyterminal domain beginning at residue 107 is associated with a number of identified biological actions including inhibition of osteoclast-mediated bone resorption and anabolic effects in bone via a region termed "osteostatin" as well as a nuclear export sequence (NES) $(43,47)$. 


\section{Endocrine, Autocrine, and Paracrine Activity of PTHrP}

In normal physiology, PTHrP acts as a hormone to control calcium transport across the placenta to the fetus (48) and during lactation when it enters systemic circulation (49). In HHM, PTHrP secreted by tumors in the breast and lung, for instance, also acts as a hormone distantly to increase bone resorption $(1,2)$. The autocrine and paracrine roles of PTHrP in normal postnatal physiology have been reviewed extensively elsewhere $(44,46)$. Thus, several of these physiologic functions that are less pertinent to this review will only briefly be mentioned here. PTHrP is highly expressed in human tissues and plays important roles in mammary gland development, tooth eruption, keratinocyte differentiation for hair follicle development, chondrocyte maturation, and endochondral bone formation $(44,46)$. Perhaps one of the most well-studied paracrine functions of PTHrP is the regulation of normal bone remodeling where it is produced locally by early osteoblast progenitors to promote differentiation of mature osteoblasts and bone formation $(50,51)$. PTHrP also inhibits apoptosis of early and mature osteoblasts and osteocytes. Furthermore, osteoblast-derived PTHrP stimulates osteoclast differentiation to increase bone resorption. These actions of PTHrP must occur in a balanced manner to maintain the integrity of the bone. While physiologic, these paracrine functions of PTHrP can also pathologically fuel osteolysis and the growth of bone disseminated tumors as discussed previously $(17,18)$. Lastly, PTHrP plays a well-recognized role as a paracrine regulator of smooth muscle relaxation, particularly in the vasculature (52) where incubation with PTHrP (1-34aa) also activates cAMP production, indicating that this effect is indeed mediated through PTH1R $(53,54)$. In vascular smooth muscle cells, treatment with exogenous PTHrP acting through PTH1R inhibits cell proliferation $(55,56)$.

In addition to binding and activating PTH1R to exert its paracrine/autocrine functions, PTHrP can translocate into the nucleus when its NLS forms a complex with importin $\beta$, a nuclear transport factor, and the GTP-binding protein Ran (57). Interestingly, in vascular smooth muscle cells, intracrine actions of PTHrP localized to the nucleus paradoxically increase proliferation (56). Indeed, in A10 smooth muscle cells overexpressing wild-type PTHP, the protein localizes in the nucleus of cells that are dividing or completing cell division. This is in striking contrast to findings that PTHrP inhibits proliferation and cell cycle progression in the same cells when acting through PTH1R $(55,56)$. These effects of PTHrP are particularly important in the discussion of its role as a regulator of tumor dormancy as it has also been demonstrated that PTHrP lacking the NLS arrests cell cycle progression by increasing p27 ${ }^{\mathrm{Kip}}$, a cyclin dependent kinase inhibitor, and decreasing phosphorylation of $\mathrm{Rb}(58,59)$. Cell cycle arrest in the G0-G1 phase is a key characteristic of quiescent cells $(60,61)$ and p27 is elevated in G0 arrested cells $(62,63)$. These findings in vascular smooth muscle cells are remarkable as they indicate that PTHrP can have paradoxical roles on mitogenesis depending on the mode of signaling: paracrine/autocrine vs. intracrine.
In addition to nuclear localization mediated by importin $\beta$, PTHrP can also gain entry into the nucleus by other mechanisms. PTHrP can be secreted but then internalized in an autocrine/paracrine manner via the PTH1R before being shuttled to the nucleus (64). Secreted PTHrP may also enter the nucleus through endocytosis-dependent translocation initiated by binding with a non-PTH1R cell surface receptor (65). Another potential mechanism regulating its subcellular localization is if translation is initiated at a codon different from the classic AUG site. As a known example, translation of fibroblast growth factor-3 (FGF3) can be initiated at an AUG codon resulting in direction of the peptide for secretion (66). If translation begins at an alternative upstream CUG site, FGF3 is directed into the nucleus. Like FGF3, the PTHrP prepro region has an alternative translational start site at a CUG codon (67), which may serve a similar purpose in regulating PTHrP secretion vs. nuclear import. Since the differential localization of PTHrP produces divergent mitogenic cellular effects in vascular smooth muscle cells, the same is likely true in cancer cells, complicating the understanding of PTHrP as a regulator of cell proliferation and tumor dormancy. Consequently, if altering PTHrP nuclear localization is to be leveraged for therapeutic purposes, more investigation is needed to better understand the regulation of PTHrP subcellular localization in cancer cells and how this may change throughout tumorigenesis.

\section{ROLES OF PTHRP IN TUMORIGENESIS, METASTASIS, AND TUMOR DORMANCY \\ Preclinical Evidence for PTHrP Regulation of Tumor Growth and Proliferation}

Our understanding of the paracrine/autocrine and intracrine actions of PTHrP extends far beyond the physiologic activities described in the bone, vasculature, and various other normal epithelial tissues. PTHrP also modulates growth, progression, and metastasis in various cancer types by regulating: (i) cell survival, (ii) cell proliferation, (iii) apoptosis, and (iv) invasion and migration $(68,69)$. For example, human MCF7 breast cancer cells overexpressing PTHrP ( -36 to -139$)$ display significantly greater survival as they are protected from serum starvation-induced apoptosis and express elevated levels of the antiapoptotic proteins $\mathrm{Bcl}-2$ and $\mathrm{Bcl}-\mathrm{xL}$ (69). Other studies have demonstrated that PTHrP drives breast tumor growth by promoting proliferation, as demonstrated by increased staining for the proliferative markers Ki67 and cyclin D1 (61). Human breast cancer cells expressing PTHrP ( -36 to -139$)$ are also enriched in the G2/M cell cycle phase compared with cells overexpressing NLS-mutated PTHrP, indicating an intracrine role for PTHrP in regulating cell cycle progression and cell growth. In prostate cancer cells, PTHrP expression stimulates proliferation and induces intracrine production of Il-8, a known growth-promoting factor (70). Prostate cancer cells overexpressing full-length PTHrP also show significantly increased cell survival when exposed to various apoptotic agents (71). Another study determined that treatment with PTHrP 
neutralizing antibodies dramatically inhibits clear cell renal cell carcinoma cell proliferation in vitro and induces regression of implanted tumors by inducing apoptosis in vivo, further indicating a role for PTHrP in regulating both proliferation and cell death (72). PTHrP also positively regulates LoVo human colon cancer cell proliferation, migration and invasion in vitro (73). Lastly, human cancer cells that overexpress full-length PTHrP display upregulated expression of the $\alpha 1, \alpha 5, \alpha 6$, and $\beta 4$ integrin subunits (74), which are known to facilitate cancer cell adhesion, migration and invasion $(75,76)$.

PTHrP expression in the primary tumor has also been identified as an important regulator of tumor growth in in vivo genetic models. In the PyMT-MMTV (mouse mammary tumor virus-polyoma middle $\mathrm{T}$ antigen) model of breast carcinoma where mice spontaneously develop mammary tumors, CreloxP-mediated Pthlh ablation delays primary tumor initiation and inhibits tumor progression (68). Palpable tumors appear much later and measure smaller than those in control mice. Mechanistically, the authors found reductions in the expression of Ki67, factor VIII (an angiogenesis marker), Bcl-2 (an antiapoptotic protein), cyclin D1 (a cell-cycle regulator), and AKT1 (a pro-survival factor). These data indicate that in this model of breast cancer, PTHrP acts as a pro-tumorigenic factor that drives tumor cell growth and proliferation in the primary site. In striking contrast, another in vivo study found that Cre-mediated loss of PTHrP in the MMTV-neu mouse model increases tumor incidence and reduces survival (77). In comparing these discrepant results from the studies on the PyMT-MMTV mice (68) vs. the MMTV-neu mice (77), it is important to note that the neu-based model reflects lateonset oncogenesis representing tumors arising in older animals while the PyMT-MMTV-based model reflects earlier onset tumorigenesis. Age can significantly affect tumor behavior (78, 79). Thus, in these pre-clinical tumor models, age at which cancer develops must be carefully factored into the interpretation of the effects of PTHrP on tumorigenesis. Lastly, authors of the PyMTMMTV study report that they deleted exon 4, which encodes amino acids 1-137 in mice (44). While the authors of the MMTVneu study do not explicitly state which portion of the gene was targeted, deletion of a different exon or smaller portion of the gene could explain these opposing observations since targeting different domains of the PTHrP molecule can elicit distinct cellular responses.

The previously discussed in vivo studies all rely on mouse tumor models. However, it is important to also recognize the utility of studies investigating PTHrP using models of spontaneous cancers that develop in larger animals such as dogs and cats (80). These animal models also contribute to our understanding of the biology of PTHrP and its role in tumorigenesis in ways that are distinct from studying rodent models alone. For instance, in feline oral squamous cell carcinoma (OSCC), elevated expression of PTHrP [which displays a high degree of sequence similarity to human isoforms (81)] is associated with increased bone invasion and osteoclastogenesis (82). Interestingly, tumor cells derived from bone specimens with evidence of osteolysis have more nuclear localization of PTHrP compared to OSCC without osteolysis.
This model provides a unique finding where in addition to the paracrine actions of PTHrP in the bone, the intracrine functions of the polypeptide also appear to strongly influence the osteolytic phenotype of tumor cells. A feline oropharyngeal squamous cell carcinoma cell lines (SCCF1) has also been developed that expresses elevated PTHrP mRNA and protein in response to TGF- $\beta$ stimulation (83) similar to human cancer cell lines (19, 84). Elevated PTHrP expression has also been noted in numerous neoplastic canine tissues compared with normal matched tissue $(85,86)$. There is great potential to learn even more about the biology of PTHrP and its role in tumorigenesis using these large animal models.

\section{PTHrP's Role in Regulating Tumor Cell Dormancy}

Most pre-clinical data support a pro-tumorigenic role for PTHrP. $\mathrm{PTHrP}$ is also likely a negative regulator of tumor cell dormancy due to its actions that modulate proliferation, apoptosis and cell survival. One study that provides some of the most direct and striking evidence to support this found that in $\mathrm{ER}^{+}$human MCF7 breast cancer cells, which lie dormant in vivo following intracardiac injection $(28,87-89)$, overexpression of PTHrP (1141) pushes these cells out of quiescence, switches them to a highly osteolytic phenotype and dramatically increases tumor burden in the bone (87). Consistent with this enhanced bone colonization and exit from dormancy, a later study determined that PTHrP (1-139) overexpression in MCF7 cells also represses expression and downstream signaling of leukemia inhibitory factor receptor (LIFR), a known breast tumor suppressor and dormancy factor in the bone (28). In this study, overexpression of PTHrP and loss of LIFR both enable otherwise dormant breast cancer cells to downregulate several quiescence- associated genes including thrombospondin-1 (TSP1) (90), transforming growth factor- $\beta 2$ (TGF- $\beta 2$ ) (91), tropomyosin-1 (TPM1) (92), and Selenbp1 (93), among others. Common regulation of this group of genes suggests that PTHrP may inhibit pro-dormancy signaling mediated by LIFR. Moreover, intracardiac injection of MCF7 LIFR knockdown cells into mice results in greater bone destruction via increased osteoclastogenesis and tumor cell proliferation (28). Thus, repression of LIFR either directly or perhaps through PTHrP overexpression can push bonedisseminated breast tumor cells out of dormancy. These data are further supported by the PyMT-MMTV genetic studies by Li et al. (68), which demonstrated that Pthlh ablation reduces primary breast tumor growth with reductions in pro-proliferative factors Ki67 and cyclin D1 as well as the anti-apoptotic protein Bcl-2, all factors known to regulate dormancy.

Interestingly, evidence exists suggesting that multiple breast cancer cell lines express PTH1R at varying levels, but do not activate downstream cAMP signaling in response to $\mathrm{PTH}$ or PTHrP, despite functional signaling in response to calcitonin and $\mathrm{PGE}_{2}$ which serve as positive controls (94). In this study, there was also no activation of a cAMP response element reporter construct, and RNA sequencing confirmed that only 2 out of 36 genes in a previously described 
panel of cAMP responsive element binding protein (CREB)responsive genes (95) were significantly upregulated in MCF7 PTHrP-overexpressing cells. Taken together, these data provide convincing evidence that in the bone colonization models, the effects of PTHrP overexpression on gene expression, including dormancy-associated factors in MCF7 cells, are independent of PTH1R activation of the cAMP/PKA/CREB pathway. Further studies are warranted to explore non-PTH1R mediated actions, which may reveal novel mechanisms by which PTHrP negatively regulates dormancy in bone-disseminated breast tumor cells.

Lastly, other studies in breast cancer have also revealed that PTHrP may alter adhesion to extracellular matrix (ECM) cell surface receptors, which can trigger intracellular signaling that promotes cell cycle progression and exit from a dormant state (96-98). Specifically, PTHrP regulates the expression of integrins which mediate interactions between tumor cells and the ECM that can modulate cellular quiescence (99). For example, downregulation of the urokinase plasminogen activator receptor (uPAR), a known mediator of tumor dormancy in vivo, decreases complex formation with $\alpha 5 \beta 1$ integrin and cell adhesion to fibronectin (100). This reduced ECM binding consequently maintains tumor cells in a dormant state by inhibiting activation of extracellular regulated kinase (ERK) signaling, which normally functions to promote cell cycle progression and division (101). Additional studies have also confirmed that inhibiting ERK signaling via altered uPAR-mediated $\alpha 5 \beta 1$ integrin interactions promotes quiescence in vivo (102). This is highly relevant in the evaluation of PTHrP as a regulator of dormancy since overexpression of PTHrP ( -36 to -139$)$ in MDA-MB-231 human breast cancer increases adhesion to fibronectin (103). PTHrP ( -36 to -139$)$ overexpression in tumor cells also significantly increases mRNA and cell surface expression of various integrins including $\alpha_{5}, \alpha_{6}, \beta_{1}$, and $\beta_{4}$. Though it has not been directly studied, PTHrP may push tumor cells out of dormancy by inducing integrin expression, cell adhesion to fibronectin, and activation of ERK signaling. Additional studies are needed to understand how PTHrP alters ECM binding to regulate tumor dormancy.

Prostate tumors, like breast tumors, also exhibit long latency periods before micrometastases become clinically detectable (37, 92). One study found direct evidence that PTHrP promotes prostate cancer progression in the bone (104). Overexpression of PTHrP (1-87) and PTHrP (1-173) in the non-invasive DU-145 human prostate cancer cell line converted these cells to an aggressive phenotype resulting in significantly greater bone tumor burden and mixed osteolytic/osteoblastic lesions following intrafemoral injection. Interestingly, mice injected with PTHrP (1-173) cells had more extensive bone lesions than those injected with PTHrP (1-87) mice despite lower serum PTHrP levels. Not only does this study demonstrate that PTHrP expression can push prostate tumor cells out of dormancy but it also highlights the pleiotropic actions of the protein's different domains, as PTHrP (1-87) lacks the full nuclear localization sequence, osteostatin region, and mitogen regulatory sequences contained in the carboxy terminus of the full-length molecule. The effects of the carboxy terminus of PTHrP, in particular, need to be examined more extensively to specifically understand how this region promotes cancer progression in bone and regulates tumor dormancy. Another study of early prostate adenocarcinoma also demonstrated that PTHrP overexpression significantly increases primary tumor growth (105). This study found no difference in growth rates between human prostate cancer cells transfected with fulllength PTHrP and vector controls, but PTHrP overexpression did render the cells less susceptible to phorbol-12-myristate13-acetate (PMA)- induced apoptosis. Other studies have also identified a role for PTHrP in inhibiting apoptosis $(106,107)$. Thus, PTHrP may negatively regulate tumor dormancy by not only increasing cell proliferation, but also by disrupting the balance with cell death.

Interestingly, other in vitro studies, particularly on tumor cells in soft tissues have provided contrasting findings on the role that PTHrP plays in tumor dormancy. Administration of neutralizing antibodies against PTHrP (1-34) to mice inoculated with PTHrPexpressing orthotopic lung carcinomas significantly increases tumor growth (108). In a later study by the same authors on human lung adenocarcinoma lines that are normally PTHrPnegative, ectopic expression of PTHrP (1-87) induces arrest in or slows progression through G1 compared with control cells (109). Expression of cyclin D2 and cyclin A2 were also lower while expression of $\mathrm{p} 27^{\mathrm{Kip} 1}$, a cyclin-dependent kinase inhibitor, was increased indicating that PTHrP inhibits the proliferation of lung tumor cells and may actually promote dormancy in this tumor model. It is interesting to note that in this study, as in the breast cancer study by Johnson et al. (94) discussed previously, there was no observed increase in cAMP production, making autocrine/paracrine signaling via PTH1R unlikely. In addition, the plasmid for PTHrP (1-87) encodes a truncated protein lacking the full NLS suggesting that extra-nuclear forms of the protein may interact with other cytoplasmic factors to regulate tumor cell proliferation. However, it is worth noting that peptides $<50-60 \mathrm{kDA}$ such as PTHrP (1-87) can still passively enter the nucleus without an NLS (110). Thus even truncated forms of PTHrP that lack the NLS may still localize to the nucleus. This further highlights the necessity of more studies to establish whether the mitogenic and dormancy effects of PTHrP depend on autocrine/paracrine, or intracrine mechanisms.

The studies on breast, prostate and lung cancer discussed in the previous sections do present mixed findings regarding the role of PTHrP in regulating tumor growth and dormancy. This would suggest that the actions of PTHrP are highly dependent on the tumor type and microenvironment. In the bone, tumor cell autonomous actions of PTHrP promote emergence from a quiescent state $(28,87,104)$. This may be complemented by paracrine actions of tumor-secreted PTHrP on bone marrow stromal cells like osteoclasts that promote the release of additional pro-tumorigenic factors to further increase tumor growth. However, in tumors and metastases that arise in other soft tissues, the opposite may be true. This is also evident in another in vivo small cell lung cancer study where administration of an anti-PTHrP antibody significantly inhibits bone metastasis formation, but not metastasis to visceral organs (lungs, liver, kidneys, lymph nodes) (14). This suggests that PTHrP may uniquely drive metastasis formation in the bone, but 
not other soft tissues. Clinical evidence of PTHrP's unique role in metastasis to bone vs. soft tissues will be discussed further in later sections. This is particularly important as the potential success of PTHrP targeted therapies will depend on careful selection of patients with tumor types at highest risk for recurrence in organs where its expression actually drives exit from dormancy and metastatic outgrowth.

\section{PTHrP's Role in Regulating Tumor Mass Dormancy}

In addition to modulating cellular dormancy, PTHrP's role in regulating angiogenesis and immunosurveillance, the two key mechanisms that characterize tumor mass dormancy, must also be considered. Angiogenesis is critical as tumors generally cannot exceed $2-3 \mathrm{~mm}$ in diameter without developing new blood vessels or co-opting pre-existing vasculature to avoid growth-limiting oxygen deprivation due to hypoxia (low oxygen tensions) and nutrient deprivation (111). Importantly, the bone marrow is a physiologically hypoxic microenvironment (112, 113) and hypoxia is evident in most solid tumors (114). Angiogenic dormancy results when insufficient vascularization induces cell death that counterbalances the rate of proliferation, resulting in no net growth of the tumor mass $(60,115)$. Emergence from dormancy and tumor progression may resume after an "angiogenic switch" in which there is a shift in the balance between pro-angiogenic factors [e.g., vascular endothelial growth factor (VEGF)] and anti-angiogenic factors (e.g., thrombospondin-1) (116). Consequently, pro-angiogenic signaling dominates and new blood vessels form.

Several studies have investigated the effects of PTHrP on tumor-induced angiogenesis, though the results are conflicting. Early work by Bakre et al. demonstrated that PTHrP inhibits endothelial cell migration in vitro and angiogenesis in prostate tumors in vivo through activation of protein kinase A (117). Consistent with this inhibitory effect, PTHrP reduces VEGF production during osteoblast differentiation and endochondral bone formation (118). These results suggest that PTHrP may prevent tumor growth by inducing angiogenic dormancy. However, numerous other studies have demonstrated that PTHrP stimulates tumor-induced angiogenesis. PTHrP increases expression of pro-angiogenic factors including VEGF (119), and factor VIII (68) in breast cancer bone metastases. In prostate cancer cells PTHrP overexpression stimulates IL-8 production, another key pro-angiogenic factor (70). Malignant pituitary tumor cells that overexpress PTHrP also induce neovascularization in xenografts in vivo (120). Mechanistically, recombinant PTHrP (1-34) increases capillary formation by endothelial cells through PTH1R activation and cAMP signaling. Another study found that exogenous PTHrP treatment in vivo increases expression of VEGF and CD31 (a marker of vascular endothelial cells) in colorectal tumors (118).

Overall, these studies indicate that PTHrP promotes tumorinduced angiogenesis, making it plausible that the protein could act as a key negative regulator of tumor dormancy by stimulating new vessel formation. Conflicting findings are likely due to diversity within the tumor microenvironment where there are different target cells of PTHrP that each may individually regulate angiogenesis. Moreover, different domains and biologically active fragments of PTHrP likely will have differing effects on endothelial cells and other stromal cells during angiogenesis, but these studies did not explore differences between the different PTHrP isoforms. Lastly, it is important to note that while angiogenesis and angiogenic dormancy can be regulated by both hypoxia and PTHrP activity, PTHrP is also regulated by hypoxic signaling. Studies in chondrocytes determined that PTHrP expression is induced by hypoxia in a HIF1 $\alpha$ (hypoxia inducible factor 1 alpha) and HIF2 $\alpha$ (hypoxia inducible factor 2 alpha) dependent manner (121). However, it has been show in prostate cancer cells that while HIF1 $\alpha$ and HIF $2 \alpha$ are both able to bind to the PTHLH promoter, only HIF $2 \alpha$ induces transcription (122). As hypoxia has been shown to have dual roles in both promoting and negatively regulating quiescence $(123,124)$, PTHrP's complex role in angiogenesis may be yet another mechanism by which low oxygen tensions differentially regulate tumor dormancy.

Immunosurveillance plays a well-characterized role in suppressing tumor growth and maintaining micrometastases in a dormant state (125). Components of the adaptive immune system including $\mathrm{CD}^{+}(126,127)$ and cytotoxic $\mathrm{CD}^{+}(128)$ $\mathrm{T}$ cells are key players known to limit the outgrowth of dormant disseminated tumor cells (129). Natural killer (NK) cells are a pivotal component of the innate immune system that can maintain tumors in a dormant state by both their cytotoxic activity as well as stimulation of anti-tumorigenic cytokine production by $\mathrm{CD}^{+}$and $\mathrm{CD}^{+} \mathrm{T}$ cells $(130,131)$. In contrast, regulatory $\mathrm{T}$ cells (Tregs) are associated with immune suppression and tumor progression in numerous cancer types $(132,133)$. Lastly, the myeloid-derived suppressor cells (MDSCs) are a unique subpopulation of immature myeloid cells that play a prominent role in reactivating dormant disseminated tumor cells and promoting metastatic outgrowth by promoting immune suppression and angiogenesis (134, 135). While few studies have examined the role of PTHrP in modulating tumor infiltration of each of these immune cell types, a few have specifically examined the MDSCs that are identified by the expression of myeloid cell (CD11b) and granulocytic (Gr-1) markers (136). One study found that treatment with recombinant PTHrP or overexpression of the protein both promote the recruitment of $\mathrm{CD} 11 \mathrm{~b}^{+} \mathrm{Gr}^{+}$MDSCs into prostate tumor tissue where they increase primary tumor growth in vivo (137). In the bone marrow, tumor-derived PTHrP also promotes recruitment and activation of $\mathrm{CD}_{11 \mathrm{~b}}{ }^{+} \mathrm{Gr}^{+} \mathrm{MDSCs}$, resulting in increased MDSC-derived MMP-9 expression, which drives prostate cancer invasion and angiogenesis. Similar findings were demonstrated in a separate study of murine mammary carcinoma where intratumoral $\mathrm{CD} 11 \mathrm{~b}^{+} \mathrm{Gr} 1^{+}$cell recruitment enhanced metastatic outgrowth via increased metalloproteinase activity (138). $\mathrm{CD}_{11 \mathrm{~b}^{+}} \mathrm{Gr}^{+}$MDSCs derived from the bone marrow of breast tumor-bearing mice also have elevated expression of transforming growth factor $\beta$ (TGF $\beta$ ), a well-known potent stimulator of PTHrP expression, thus perpetuating the cycle of tumor-induced osteolysis that fuels tumor growth (139). Taken together, these results suggest 
that PTHrP may play a critical role in negatively regulating tumor mass dormancy by increasing infiltration of immune suppressive MDSCs, which promote tumorigenesis $(140,141)$. PTHrP actions on recruitment of other immune populations in the tumor microenvironment have been inadequately explored. These studies are critical to gaining a more complete understanding of the role of PTHrP as a regulator of tumor mass dormancy.

\section{Clinical Evidence for PTHrP Effects on Tumor Growth and Metastasis}

Much like the in vitro and in vivo analyses, clinical studies investigating PTHrP as a prognostic factor have produced opposing findings, complicating the understanding of the role of the molecule in tumorigenesis, metastasis, and tumor dormancy. Henderson et al. conducted a large and comprehensive prospective study over 10 years in patients with breast cancer and found that positive immunohistochemical staining for PTHrP in $79 \%$ of the primary tumors was associated with significantly improved survival and decreased bone metastasis (142). These results would suggest that PTHrP decreases the invasive capacity of breast tumor cells and is protective against tumor growth in the primary site and formation of distant metastases. Interestingly, this study also revealed that of the 19 patients with bone metastases requiring surgical intervention, 7 patients had PTHrP-negative primary tumors. However, the majority of the individuals with PTHrP-negative primary tumors still developed PTHrP-positive bone lesions. All patients in the study with PTHrP-positive primary cancers also had positive expression in their bone metastases. Thus, there is not a clear inverse relationship between PTHrP expression at the primary and bone secondary sites. It is important to note this frequency of bone metastases in patients with PTHrP-negative primary breast cancers is still consistent with known tumorigenic roles for PTHrP when tumor cells colonize the bone later in disease progression. The bone marrow microenvironment enhances tumor cell production of PTHrP, which drives osteolysis and further metastatic growth $(17,18)$. Thus, protective PTHrP actions early in tumorigenesis at the primary site are likely distinct from its deleterious effects once disseminated tumor cells reach the bone.

Another breast cancer study that aligns with the overall conclusions of Henderson et al. (142) found that PTHrP levels are downregulated in malignant compared with normal breast epithelia, but also low levels of nuclear localized PTHrP correlate with unfavorable clinical outcomes (143). Mechanistically, the authors found a strong positive correlation between nuclear PTHrP levels and nuclear pStat5. This may explain, in part, why nuclear PTHrP is associated with the unfavorable clinical outcomes since loss of Stat 5 expression and activation in breast cancer has consistently been associated with poor prognosis (144, 145). Again, this observed progressive loss of nuclear PTHrP from well-differentiated mammary epithelia to poorly differentiated, aggressive cancer cells would suggest important context-dependent roles for PTHrP signaling in tumorigenesis. In early stages, intracrine signaling of nuclear PTHrP may be protective against malignant transformation, but in distant sites like the bone, reactivation of PTHrP can still induce extensive osteolysis that would drive metastatic tumor growth.

Other clinical studies have identified protective roles of PTHrP in other solid tumor types. An analysis of non-small cell lung cancer (NSCLC) determined that PTHrP (109-141) expression in the primary tumor was associated with longer disease-free survival in female patients with either early or advanced stages of disease (146). Interestingly, female patients in this study with PTHrP-negative cancer had a shorter lifespan than all other participants, including male patients with PTHrPnegative or positive carcinomas. Thus, absence of tumor PTHrP appears to be a negative prognostic indicator specifically in women with NSCLC. The exact etiology of the sex dependence of PTHrP as a prognostic factor in lung cancer has not been further studied. However, $17 \beta$-estradiol $\left(\mathrm{E}_{2}\right)$ and tamoxifen have both been shown to regulate PTHrP expression in breast cancer cells (147), suggesting an association between estrogen receptor signaling and PTHrP during tumorigenesis. Lastly, in clear cell renal cell carcinoma (RCC), it has also been determined that decreased intensity of the carboxy-terminal region of PTHrP (amino acids 109-141) is associated with significantly greater cases of tumor recurrence (148). This would suggest a role for PTHrP in increasing recurrence free survival in patients with RCC.

By contrast, numerous other clinical studies, especially in breast cancer, have concluded that PTHrP supports tumor growth and progression. In a large analysis including two genome-wide association studies from 41 case-control studies through the Breast Cancer Association Consortium (BCAC) and nine breast cancer genome-wide association studies, $P$ THLH was identified as a susceptibility locus in both $\mathrm{ER}^{+}$and $\mathrm{ER}^{-}$breast cancer (149). This study of patients with invasive breast cancer and ductal carcinoma in situ (DCIS) provides additional evidence implicating PTHrP in breast cancer pathogenesis, independent of its roles in promoting osteolysis. It is important to note that this analysis was performed on data from retrospective casecontrol studies enrolling multiple smaller patient cohorts. This factor should be kept in mind when comparing these findings with those of the better-powered, prospective study conducted by Henderson et al. (142) that identified PTHrP as a protective factor. In another study on patients with $\mathrm{ER}^{+}$and $\mathrm{ER}^{-}$breast cancer, expression of both PTHrP and its receptor correlated with reduced disease-free survival while receptor expression alone correlated with reduced overall survival (150). In this study, PTHrP expression was detected by an antibody to the amino terminal region (1-34) in $68 \%$ of primary tumor specimens compared with $100 \%$ of bone metastases and the PTHrP receptor was present in $37 \%$ of tumors compared with $81 \%$ of bone metastasis samples. Thus, PTHrP and its receptor are expressed more frequently in bone metastases than primary tumors. However, the functional relevance of this pattern of receptor expression in bone-disseminated tumor cells is still unclear since in vitro data indicate that in $\mathrm{ER}^{+}$breast cancer cells, activation of PTH1R/cAMP signaling does not regulate dormancy gene expression (95). Nevertheless, while expression of the receptor may not regulate dormancy in the bone, these clinical data 
still support the understanding that PTHrP expression by bone disseminated tumor cells is critical to their ability to establish metastatic colonies and possibly promote exit from dormancy. Other studies have also confirmed a positive association between PTHrP expression in primary breast tumors and bone metastasis as well as shortened overall survival $(151,152)$.

Though in a different metastatic site, a recent study on early stage triple negative breast cancer (TNBC) found that PTHrP expression is significantly correlated with decreased central nervous system (CNS)-progression free survival (153). These findings, if validated in other large cohorts of early-stage, newly diagnosed TNBC patients, would raise the hypothesis that monitoring PTHrP expression in TNBC patients could detect the initial stages of CNS metastasis and identify individuals with recurrent tumors much earlier than conventional detection techniques. Interestingly, this study did not identify a statistically significant relationship between PTHrP expression and the incidence of bone metastasis. It is important to note that only specimens from patients with early stage TNBC without evidence of metastasis at presentation or multiple primary malignancies were analyzed. Thus, examination of patients with later staged cancer may also reveal a significant association between PTHrP expression and bone metastasis in TNBC. This highlights the importance of examining patients with all subtypes of breast cancer and stages of disease progression when investigating $\mathrm{PTHrP}$ as a prognostic factor for metastasis and late recurrence.

Clinical evidence also exists suggesting a role for PTHrP in tumor growth and metastasis in other tumor types. In prostate cancer, PTHrP expression varies depending on the cancer stage, with expression detected in $33 \%$ of benign prostate hyperplasias, $87 \%$ of well-differentiated tumors and $100 \%$ of poorly differentiated and metastatic tumors (154). Other studies have similarly found that PTHrP is expressed in prostatic bone metastases (155). Here it seems that a progressive gain of PTHrP in disease progression is associated with tumorigenesis and distant metastasis. In a study of patients with early-stage lung adenocarcinoma, positive staining for PTHrP (1-34) is associated with worse overall survival and metastasis-free survival, independent of tumor stage (156). Survival is even more dramatically reduced in patients with tumors co-expressing high levels of N-terminal PTHrP and PTH1R. Taken together, these observations would suggest that paracrine/autocrine mechanisms involving PTHrP may drive tumor progression in lung cancer.

\section{AUTHORS PERSPECTIVES ON PTHrP AS A PROGNOSTIC FACTOR AND DORMANCY REGULATOR}

Given the conflicting data from both preclinical and clinical studies, a general consensus has not yet been reached regarding the role of PTHrP in tumorigenesis, metastasis, and tumor dormancy. However, there are numerous factors to consider when reconciling these findings. Stage of disease progression is critically important in this discussion. In general, the clinical data suggest that early in tumorigenesis at the primary site, PTHrP inhibits cancer growth and progression since its expression is associated with improved survival and decreased metastasis in patients with various tumor types $(142,146,148,153)$ (Figure 1). In these cases, tumor cell autonomous actions of PTHrP to alter cell proliferation may account for these findings (68). Late in disease progression, after dissemination to the bone marrow, the growth of surviving tumor cells is driven by increased PTHrP production to stimulate osteoclast-mediated bone resorption, which releases pro-tumorigenic factors that further drive tumor growth and additional PTHrP secretion $(17,18)$ (Figure 2). These paracrine actions of PTHrP mediated by PTH1R signaling in osteoblasts are necessary for bone metastasis growth and would explain clinical findings that PTHrP is associated with reduced disease-free survival and metastasis formation $(151,152)$. Lastly, the preclinical data clearly indicate that increased PTHrP expression drives breast tumor cells out of their quiescent state $(28,87,94)$ via a mechanism independent of canonical PTH1R activation. Again, later in disease progression after long latency periods, increased PTHrP expression would favor exit from tumor dormancy in the bone and likely other metastatic sites (Figure 1). This hypothesis is supported by preclinical findings that PTHrP downregulates pro-dormancy gene expression (28), promotes proliferation, and inhibits apoptosis $(61,104)$ which are two key cellular responses that must be carefully balanced to regulate tumor dormancy.

As noted earlier in this review, PTHrP is a molecule with multiple biologically active domains that control its autocrine/paracrine and intracrine actions. Each of these individual actions must be considered when interpreting data on PTHrP as a dormancy regulator and prognostic factor. Preclinical studies have directly demonstrated that manipulating the expression of different PTHrP isoforms elicits markedly different biological responses. A striking example of this comes from Deftos et al. (104) where mice injected with dormant prostate cancer cells expressing the full-length PTHrP (1-173) molecule developed more extensive bone lesions than those injected with PTHrP (1-87) which lacks the full NLS, osteostatin region, and critical mitogen regulatory sequences contained in the carboxy terminus. Findings such as these can be accounted for by multiple factors. There are likely important functional elements in the region of PTHrP spanning amino acids 88173 that uniquely promote tumor progression in bone but have not been fully elucidated. Furthermore, truncated forms of PTHrP may also assume different tertiary structures which alter binding to or interactions with other proteins that may drastically influence tumor cell behavior. Preclinical studies to further elucidate the biological activity of each PTHrP domain will be critically important to understanding the complexity of the molecule's effects in tumor development.

In interpreting findings from clinical studies on survival and prognosis in human patients, a third factor to consider is the epitope used to define positive and negative expression, as nearly all of these analyses utilize immunohistochemistry to detect PTHrP. For instance, in their work on NSCLC, Montgrain et al. (146) specifically investigated PTHrP (1-34) expression while Monego et al. (156) probed for PTHrP (109-141) and found opposite effects with regards to $\mathrm{PTHrP}$ as a prognostic indicator. 


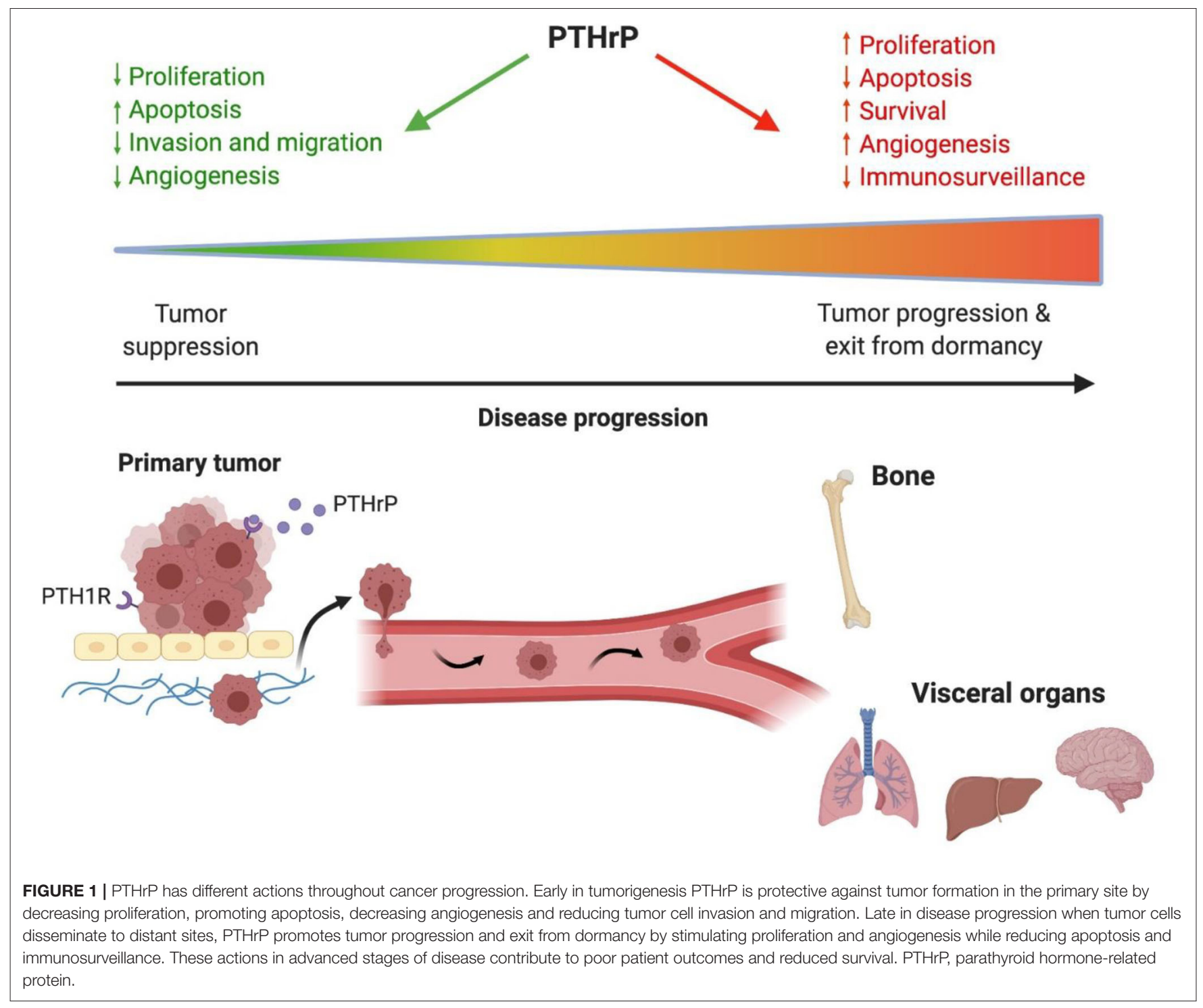

Again, amino-terminal and carboxy-terminal PTHrP regions are known to induce disparate biological effects depending on the cell type and activation of autocrine/paracrine vs. intracrine signaling. Due to posttranslational proteolytic processing, the mature PTHrP molecule can also give rise to multiple peptides with different biological activities. Fragments encompassing the amino terminal region (residues 1-36), mid-molecule regions (38-94), (38-95), and (38-101), as well as the carboxy terminal (107-139) have been detected. Multiple peptide fragments have even been isolated from plasma (157) and urine of patients with HHM (158). Thus, antibody selection is important to consider when drawing conclusions from clinical studies relying on the immunohistochemistry to analyze expression of PTHrP and any of its cleavage products as a prognostic factor.

\section{PTHrP AS A THERAPEUTIC TARGET}

Numerous studies have provided convincing evidence that PTHrP promotes tumor progression, and late recurrence by pushing tumor cells out of dormancy, resulting in poor patient survival. Thus, PTHrP would seem to be a promising therapeutic target for treating advanced human cancers. Several animal studies have demonstrated reduced distant metastasis to bone with PTHrP small molecule inhibitors (159) and neutralizing antibodies $(68,160,161)$; however, human clinical data are lacking. Furthermore, there are several limitations in our current understanding of the biological activity of PTHrP that greatly complicate the development of safe and efficacious anti-PTHrP therapies at this time. PTHrP is an incredibly complex peptide with multiple distinct domains that can each influence its actions as an endocrine, paracrine, autocrine and intracrine signaling molecule. This coupled with the fact that its different isoforms and fragments can elicit diverse cellular responses could result in PTHrP targeting therapies that inadvertently promote tumor growth and recurrence if used in the wrong patient population or stage of disease progression. This is especially true in breast cancer, where preclinical and clinical data suggest that PTHrP inhibits early tumor progression, but promotes distant metastasis 


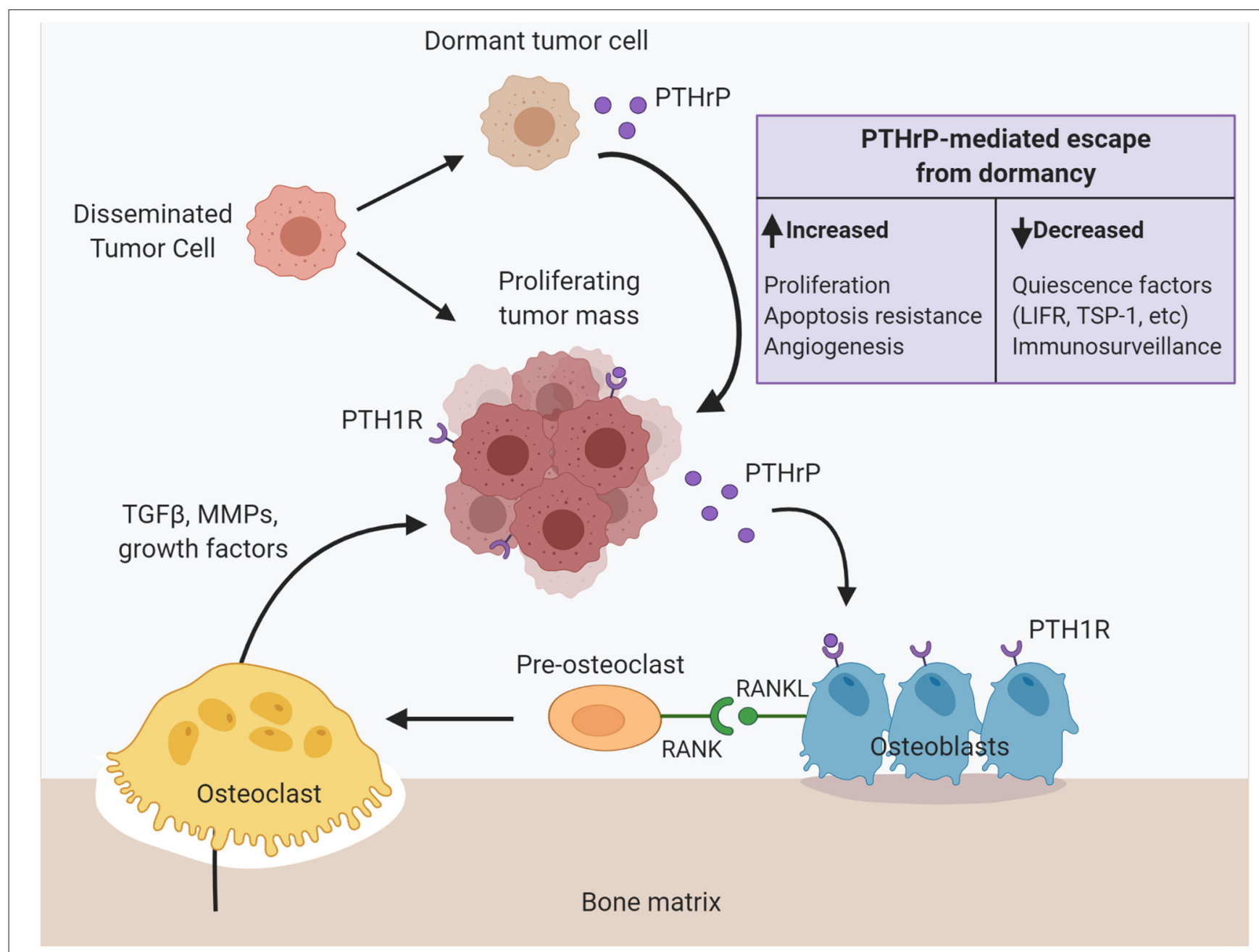

FIGURE 2 | PTHrP dictates disseminated tumor cell fate in the bone to drive metastasis formation. Upon dissemination to the bone, surviving tumor cells can proliferate into a micrometastasis. Tumor cell secretion of PTHrP signals through the PTH1 receptor (PTH1R) on osteoblast lineage cells to stimulate RANKL production and osteoclastogenesis. Osteoclast-mediated resorption releases pro-tumorigenic factors from the bone matrix such as TGF- $\beta$, matrix metalloproteinases and other growth factors that further fuel tumor cell colonization, proliferation, and PTHrP production. Alternatively, disseminated tumor cells instead enter a prolonged dormant state. PTHrP drives tumor cell escape from dormancy and metastatic outgrowth via multiple mechanisms: (1) increased proliferation, (2) apoptosis resistance, (3) increased angiogenesis, (4) decreased immunosurveillance and myeloid-derived suppressor cell recruitment, (5) decreased expression of known quiescence factors (e.g., LIFR). PTHrP, parathyroid hormone-related protein; PTH1R, parathyroid hormone-related protein type 1 receptor; RANKL, receptor activator of nuclear factor-kappa $\mathrm{B}\left(\mathrm{NF}_{\mathrm{K}} \mathrm{B}\right)$ ligand; LIFR, leukemia inhibitory factor receptor (LIFR); TSP-1, thrombospondin-1.

in advanced stages of disease (162). Studies fully defining PTHrP's role in different stages of cancer and in tumor dormancy are needed in order to identify the appropriate therapeutic window for targeting PTHrP.

In addition to direct PTHrP inhibition, alternative approaches including targeting upstream regulators of the peptide's expression have been explored. As discussed previously (20), Wnt signaling drives PTHrP expression in highly osteolytic cancer cells and thus presents a potential therapy to prevent tumor-induced bone destruction and metastatic outgrowth. However, there are challenges to targeting Wnt therapeutically due to deleterious off-target effects since signaling is critical during normal development and tissue homoestasis, especially bone formation (163-165). However, the anti-tumor activity of Wnt inhibitors has been investigated and shown varying efficacy, primarily in preclinical gastrointestinal cancer models $(166,167)$. There are also numerous ongoing clinical trials investigating inhibitors of the Wnt pathway in multiple other solid tumor types [NCT01351103, NCT03901950, NCT02675946, NCT03447470, NCT03395080]. In recent years, more cancer cell-specific molecular targets such as vacuolarATPase (v-ATPase) have been explored in the development of Wnt signaling inhibitors $(168,169)$. Bafilomycin and concanamycin, which directly bind to and inhibit v-ATPase, markedly inhibit $\mathrm{Wnt} / \beta$-catenin signaling in colorectal cancer cells in vitro and reduce tumor cell proliferation in vivo without 
significant toxicity (168). Selective inhibitors of Porcupine (PORCN), an acyltransferase that catalyzes post-translational modification and activation of WNT ligands, have also shown promising anti-tumor activity in vivo, while sparing WNTdependent tissues $(170,171)$. While inhibiting the Wnt pathway may be an effective therapy to decrease PTHrP expression for the treatment of metastatic cancers, more extensive investigation is needed to identify the most selective inhibitors and safest therapeutic window.

Alternative upstream targets include TGF- $\beta$ which upregulates expression of Gli2 and in turn increases tumor secretion of PTHrP $(172,173)$. Gli2 repression significantly reduces tumor-induced bone destruction mediated by TGF- $\beta$ signaling in human breast cancer MDA-MB-231 cells (172). Inhibitors against TGF- $\beta$ and GLI proteins have been evaluated in clinical trials as anti-cancer therapy (174) [clinicaltrials.gov]. Another study demonstrated that the EGF receptor promotes PTHrP production, since treatment with erlotinib, an EGF receptor tyrosine kinase inhibitor, suppresses PTHrP expression in non-small cell lung cancer cells and reduces osteolysis (175). Other EGF receptor tyrosine kinase inhibitors including gefitinib also reduce PTHrP levels (176). Lastly, targeting downstream effectors of PTHrP may also provide an efficacious strategy. For instance, as mentioned previously, PTHrP (1-139) overexpression in MCF7 cells also represses expression and downstream signaling of LIFR, a known breast tumor suppressor and dormancy factor in the bone (28). Consequently, LIFR downregulation promotes human MCF7 breast cancer cell emergence from dormancy in the bone. Treatment with the histone deacetylase inhibitor valproic acid subsequently increases LIFR expression in human MCF7 breast cancer cells in vitro, suggesting that targeting LIFR, a downstream factor in PTHrP signaling, may effectively maintain tumor cells in a dormant state to prevent metastatic outgrowth. Multiple strategies should therefore be considered in order to develop the most selective and effective PTHrP targeting therapies.

\section{REFERENCES}

1. Goldner W. Cancer-related hypercalcemia. J Oncol Prac. (2016) 12:426-32. doi: 10.1200/JOP.2016.011155

2. Mundy GR, Edwards JR. PTH-related peptide (PTHrP) in hypercalcemia. $J$ Am Soc Nephrol. (2008) 19:672. doi: 10.1681/ASN.2007090981

3. Ericsson Y. Simplified methods for determining of calcium and magnesium in the saliva. J Dent Res. (1955) 34:104-12. doi: $10.1177 / 00220345550340010301$

4. Albright F, Smith PH, Richardson AM. postmenopausal osteoporosis: its clinical features. J Am Med Assoc. (1941) 116:2465-74. doi: 10.1001/jama.1941.02820220007002

5. Nakayama K, Fukumoto S, Takeda S, Takeuchi Y, Ishikawa T, Miura M, et al. Differences in bone and vitamin D metabolism between primary hyperparathyroidism and malignancy-associated hypercalcemia. J Clin Endocrinol Metab. (1996) 81:607-11. doi: 10.1210/jcem.81.2.8636276

6. Moseley JM, Kubota M, Diefenbach-Jagger H, Wettenhall RE, Kemp BE, Suva LJ, et al. Parathyroid hormone-related protein purified from a human lung cancer cell line. Proc Natl Acad Sci USA. (1987) 84:5048. doi: $10.1073 /$ pnas.84.14.5048

\section{CONCLUSIONS}

$\mathrm{PTHrP}$ is a unique multifunctional protein with diverse effects on tumor cell behavior mediated by its different biological domains and isoforms that arise from posttranslational processing. Overall, preclinical and clinical studies suggest that PTHrP inhibits tumor progression in early stages of disease while it functions in the opposite manner to promote tumor development and metastasis formation in advanced cancers, resulting in diminished survival in patients. This is especially true in the bone, a common site of metastasis, where PTHrP-mediated osteolysis is critical for tumor cells to establish as colonies and grow. Furthermore, while the studies are still limited, an important role for PTHrP in promoting tumor emergence from a dormant state is an emerging area of interest. Despite its complexity, more studies that fully uncover the unique biological activities of PTHrP and its domains that regulate its endocrine, autocrine, paracrine, and intracrine signaling could uncover numerous additional targets to explore as anticancer therapeutics.

\section{AUTHOR CONTRIBUTIONS}

CE drafted the manuscript. CE and RJ edited the manuscript. All authors contributed to the article and approved the submitted version.

\section{FUNDING}

RJ and CE were supported by DoD Breakthrough Award W81XWH-18-1-0029 (RJ) and NIH award R00CA194198 (RJ).

\section{ACKNOWLEDGMENTS}

The authors wish to think Dr. T. John (Jack) Martin for his insightful comments and discussion of the manuscript text. Figures were created with BioRender.com.

7. Burtis WJ, Wu T, Bunch C, Wysolmerski JJ, Insogna KL, Weir EC, et al. Identification of a novel 17,000-dalton parathyroid hormonelike adenylate cyclase-stimulating protein from a tumor associated with humoral hypercalcemia of malignancy. J Biol Chem. (1987) 262:7151-6. doi: 10.1016/S0021-9258(18)48217-8

8. Thiede MA, Strewler GJ, Nissenson RA, Rosenblatt M, Rodan GA. Human renal carcinoma expresses two messages encoding a parathyroid hormone-like peptide: evidence for the alternative splicing of a singlecopy gene. Proc Natl Acad Sci USA. (1988) 85:4605. doi: 10.1073/pnas.85. 13.4605

9. Suva LJ, Winslow GA, Wettenhall RE, Hammonds RG, Moseley JM, Diefenbach-Jagger $\mathrm{H}$, et al. A parathyroid hormone-related protein implicated in malignant hypercalcemia: cloning and expression. Science. (1987) 237:893.

10. Coleman RE, Clinical features of metastatic bone disease and risk of skeletal morbidity. Clin Cancer Res. (2006) 12(20 Pt 2):6243s-49s. doi: 10.1158/1078-0432.CCR-06-0931

11. Johnson RW, Schipani E, Giaccia AJ. HIF targets in bone remodeling and metastatic disease. Pharmacol Ther. (2015) 150:169-77. doi: 10.1016/j.pharmthera.2015.02.002 
12. Macedo F, Ladeira K, Pinho F, Saraiva N, Bonito N, Pinto L, et al. Bone metastases: an overview. Oncol Rev. (2017) 11:321-21. doi: 10.4081/oncol.2017.321

13. Hoey RP, Sanderson C, Iddon J, Brady G, Bundred NJ, Anderson NG. The parathyroid hormone-related protein receptor is expressed in breast cancer bone metastases and promotes autocrine proliferation in breast carcinoma cells. Br J Cancer. (2003) 88:567-73. doi: 10.1038/sj.bjc.6600757

14. Miki T, Yano S, Hanibuchi M, Kanematsu T, Muguruma H, Sone S. Parathyroid hormone-related protein $(\mathrm{PTHrP})$ is responsible for production of bone metastasis, but not visceral metastasis, by human small cell lung cancer SBC-5 cells in natural killer cell-depleted SCID mice. Int J Cancer. (2004) 108:511-5. doi: 10.1002/ijc.11586

15. Wulf GG, Jürgens B, Liersch T, Gatzemeier W, Rauschecker H, Buske C, et al. Reverse transcriptase/polymerase chain reaction analysis of parathyroid hormone-related protein for the detection of tumor cell dissemination in the peripheral blood and bone marrow of patients with breast cancer. J Cancer Res Clin Oncol. (1997) 123:514-21. doi: 10.1007/s004320050097

16. Mundy GR. Metastasis to bone: causes, consequences and therapeutic opportunities. Nat Rev Cancer. (2002) 2:584-93. doi: 10.1038/nrc867

17. Kingsley LA, Fournier PGJ, Chirgwin JM, Guise TA. Molecular biology of bone metastasis. Mol Cancer Ther. (2007) 6:2609. doi: 10.1158/1535-7163.MCT-07-0234

18. Sowder ME, Johnson RW. Bone as a preferential site for metastasis. JBMR Plus. (2019) 3:e10126. doi: 10.1002/jbm4.10126

19. Ruppender NS, Merkel AR, Martin TJ, Mundy GR, Sterling JA, Guelcher SA. Matrix rigidity induces osteolytic gene expression of metastatic breast cancer cells. PLoS ONE. (2010) 5:e15451. doi: 10.1371/journal.pone.0015451

20. Johnson RW, Merkel AR, Page JM, Ruppender NS, Guelcher SA, Sterling JA. Wnt signaling induces gene expression of factors associated with bone destruction in lung and breast cancer. Clin Exp Metastasis. (2014) 31:945-59. doi: 10.1007/s10585-014-9682-1

21. Coleman R. Bone targeted treatments in cancer - the story so far. J Bone Oncol. (2016) 5:90-2. doi: 10.1016/j.jbo.2016.03.002

22. Early Breast Cancer Trialists' Collaborative Group (EBCTCG). Adjuvant bisphosphonate treatment in early breast cancer: meta-analyses of individual patient data from randomised trials. Lancet. (2015) 386:1353-61. doi: 10.1016/S0140-6736(15)60908-4

23. Gnant M, Pfeiler G, Steger GG, Egle D, Greil R, Fitzal F, et al. Adjuvant denosumab in postmenopausal patients with hormone receptor-positive breast cancer (ABCSG-18): disease-free survival results from a randomised, double-blind, placebo-controlled, phase 3 trial. Lancet Oncol. (2019) 20:33951. doi: 10.1016/S1470-2045(18)30862-3

24. Herrera Pena RA, Lei X, Chavez-MacGregor M, Zhao H, Giordano SH, Suarez-Almazor ME. Overall survival in female Medicare beneficiaries with early stage breast cancer receiving bisphosphonates or denosumab. J Clin Oncol. (2018) 36(15_suppl):530. doi: 10.1200/JCO.2018.36.15_suppl.530

25. Rennert G, Pinchev M, Gronich N, Saliba W, Flugelman A, Lavi I, et al. Oral bisphosphonates and improved survival of breast cancer. Clin Cancer Res. (2017) 23:1684. doi: 10.1158/1078-0432.CCR-16-0547

26. Suarez-Almazor ME, Herrera R, Lei X, Chavez-MacGregor M, Zhao H, Giordano SH. Survival in older women with early stage breast cancer receiving low-dose bisphosphonates or denosumab. (2020) 126:3929-38. doi: $10.1002 / \mathrm{cncr} .33035$

27. Soki FN, Park SI, McCauley LK. The multifaceted actions of PTHrP in skeletal metastasis. Future Oncol. (2012) 8:803-17. doi: 10.2217/fon.12.76

28. Johnson RW, Finger EC, Olcina MM, Vilalta M, Aguilera T, Miao Y, et al. Induction of LIFR confers a dormancy phenotype in breast cancer cells disseminated to the bone marrow. Nat Cell Biol. (2016) 18:1078-89. doi: $10.1038 / n c b 3408$

29. Klein CA, Parallel progression of primary tumours and metastases. Nat Rev Cancer. (2009) 9:302-12. doi: 10.1038/nrc2627

30. Pantel K, Alix-Panabieres C, Riethdorf S. Cancer micrometastases. Nat Rev Clin Oncol. (2009) 6:339-51. doi: 10.1038/nrclinonc.2009.44

31. Pantel K, Brakenhoff RH. Dissecting the metastatic cascade. Nat Rev Cancer. (2004) 4:448-56. doi: 10.1038/nrc1370

32. McNichols DW, Segura JW, DeWeerd JH. Renal cell carcinoma: long-term survival and late recurrence. J Urol. (1981) 126:17-23. doi: $10.1016 /$ S0022-5347(17)54359-1
33. Páez D, Labonte MJ, Bohanes P, Zhang W, Benhanim L, Ning Y, et al. Cancer dormancy: a model of early dissemination and late cancer recurrence. Clin Cancer Res. (2012) 18:645. doi: 10.1158/1078-0432.CCR11-2186

34. Tsao H, Cosimi AB, Sober AJ. Ultra-late recurrence (15 years or longer) of cutaneous melanoma. Cancer. (1997) 79:2361-70. doi: 10.1002/ (SICI)1097-0142(19970615)79:12<2361::AID-CNCR10>3.0.CO;2-P

35. Karrison TG, Ferguson DJ, Meier P. Dormancy of mammary carcinoma after mastectomy. J Natl Cancer Inst. (1999) 91:80-5. doi: 10.1093/jnci/91.1.80

36. Salvador F, Llorente A, Gomis RR. From latency to overt bone metastasis in breast cancer: potential for treatment and prevention. J Pathol. (2019) 249:6-18. doi: 10.1002/path.5292

37. Haas GP, Delongchamps N, Brawley OW, Wang CY, de la Roza G. The worldwide epidemiology of prostate cancer: perspectives from autopsy studies. Can J Urol. (2008) 15:3866-71.

38. al-Kattan K, Sepsas E, Fountain SW, Townsend ER. Disease recurrence after resection for stage I lung cancer. Eur J Cardiothorac Surg. (1997) 12:380-4. doi: 10.1016/S1010-7940(97)00198-X

39. Park YH, Baik KD, Lee YJ, Ku JH, Kim HH, Kwak C. Late recurrence of renal cell carcinoma $>5$ years after surgery: clinicopathological characteristics and prognosis. BJU Int. (2012) 110(11b):E553-8. doi: 10.1111/j.1464-410X.2012.11246.x

40. Ryuk JP, Choi G-S, Park JS, Kim HJ, Park SY, Yoon GS, et al. Predictive factors and the prognosis of recurrence of colorectal cancer within 2 years after curative resection. Ann Surg Treat Res. (2014) 86:143-51. doi: 10.4174/astr.2014.86.3.143

41. Braun S, Kentenich C, Janni W, Hepp F, de Waal J, Willgeroth F, et al. Lack of effect of adjuvant chemotherapy on the elimination of single dormant tumor cells in bone marrow of high-risk breast cancer patients. J Clin Oncol. (2000) 18:80-6. doi: 10.1200/JCO.2000.18.1.80

42. Recasens A, Munoz L. Targeting cancer cell dormancy. Trends Pharmacol Sci. (2019) 40:128-41. doi: 10.1016/j.tips.2018.12.004

43. Martin TJ, Moseley JM, Gillespie MT. Parathyroid hormone-related protein: biochemistry and molecular biology. Crit Rev Biochem Mol Biol. (1991) 26:377-95. doi: 10.3109/10409239109114073

44. Martin TJ. Parathyroid hormone-related protein, its regulation of cartilage and bone development, and role in treating bone diseases. Physiol Rev. (2016) 96:831-71. doi: 10.1152/physrev.00031.2015

45. Juppner H, Abou-Samra AB, Freeman M, Kong XF, Schipani E, Richards J, et al. A G protein-linked receptor for parathyroid hormone and parathyroid hormone-related peptide. Science. (1991) 254:1024. doi: $10.1126 /$ science. 1658941

46. McCauley LK, Martin TJ. Twenty-five years of PTHrP progress: from cancer hormone to multifunctional cytokine. J Bone Mineral Res. (2012) 27:1231-9. doi: 10.1002/jbmr.1617

47. de Castro LF, Lozano D, Portal-Núñez S, Maycas M, De la Fuente M, Caeiro JR, et al. Comparison of the skeletal effects induced by daily administration of PTHrP (1-36) and PTHrP (107-139) to ovariectomized mice. J Cell Physiol. (2012) 227:1752-60. doi: 10.1002/jcp.22902

48. Kovacs CS, Lanske B, Hunzelman JL, Guo J, Karaplis AC, Kronenberg HM. Parathyroid hormone-related peptide (PTHrP) regulates fetalplacental calcium transport through a receptor distinct from the PTH/PTHrP receptor. Proc Natl Acad Sci USA. (1996) 93:15233-8. doi: $10.1073 /$ pnas.93.26.15233

49. Lippuner K, Zehnder HJ, Casez JP, Takkinen R, Jaeger P. PTH-related protein is released into the mother's bloodstream during lactation: evidence for beneficial effects on maternal calcium-phosphate metabolism. J Bone Miner Res. (1996) 11:1394-9. doi: 10.1002/jbmr.5650111004

50. Lanske B, Amling M, Neff L, Guiducci J, Baron R, Kronenberg HM. Ablation of the PTHrP gene or the PTH/PTHrP receptor gene leads to distinct abnormalities in bone development. J Clin Investig. (1999) 104:399-407. doi: 10.1172/JCI6629

51. Martin TJ. Osteoblast-derived PTHrP is a physiological regulator of bone formation. J Clin Investig. (2005) 115:2322-4. doi: 10.1172/JCI26239

52. Maeda S, Sutliff RL, Qian J, Lorenz JN, Wang J, Tang H, et al. Targeted overexpression of parathyroid hormone-related protein (PTHrP) to vascular smooth muscle in transgenic mice lowers blood pressure and alters vascular contractility. Endocrinology. (1999) 140:1815-25. 
53. Okano K, Wu S, Huang X, Pirola CJ, Juppner H, Abou-Samra AB, et al. Parathyroid hormone (PTH)/PTH-related protein $(\mathrm{PTHrP})$ receptor and its messenger ribonucleic acid in rat aortic vascular smooth muscle cells and UMR osteoblast-like cells: cell-specific regulation by angiotensin-II and PTHrP. Endocrinology. (1994) 135:1093-9. doi: 10.1210/endo.135.3.8070351

54. Song GJ, Fiaschi-Taesch N, Bisello A. Endogenous parathyroid hormonerelated protein regulates the expression of PTH type 1 receptor and proliferation of vascular smooth muscle cells. Mol Endocrinol. (2009) 23:1681-90. doi: 10.1210/me.2009-0098

55. Ishikawa M, Akishita M, Kozaki K, Toba K, Namiki A, Yamaguchi T, et al. Amino-terminal fragment (1-34) of parathyroid hormone-related protein inhibits migration and proliferation of cultured vascular smooth muscle cells. Atherosclerosis. (1998) 136:59-66. doi: 10.1016/S0021-9150(97)00187-1

56. Massfelder T, Dann P, Wu TL, Vasavada R, Helwig J-J, Stewart AF. Opposing mitogenic and anti-mitogenic actions of parathyroid hormone-related protein in vascular smooth muscle cells: a critical role for nuclear targeting. Proc Natl Acad Sci USA. (1997) 94:13630-5. doi: 10.1073/pnas.94.25.13630

57. Cingolani G, Bednenko J, Gillespie MT, Gerace L. Molecular basis for the recognition of a nonclassical nuclear localization signal by importin beta. Mol Cell. (2002) 10:1345-53. doi: 10.1016/S1097-2765(02)00727-X

58. Fiaschi-Taesch N, Takane KK, Masters S, Lopez-Talavera JC, Stewart AF. Parathyroid-hormone-related protein as a regulator of $\mathrm{pRb}$ and the cell cycle in arterial smooth muscle. Circulation. (2004) 110:177-85. doi: 10.1161/01.CIR.0000134483.30849.B7

59. Stuart WD, Maeda S, Khera P, Fagin JA, Clemens TL. Parathyroid hormone-related protein induces G1 phase growth arrest of vascular smooth muscle cells. Am J Physiol Endocrinol Metab. (2000) 279:E60-7. doi: 10.1152/ajpendo.2000.279.1.E60

60. Aguirre-Ghiso JA. Models, mechanisms and clinical evidence for cancer dormancy. Nat Rev Cancer. (2007) 7:834-46. doi: 10.1038/nrc2256

61. Phan TG, Croucher PI. The dormant cancer cell life cycle. Nat Rev Cancer. (2020) 20:398-411. doi: 10.1038/s41568-020-0263-0

62. Deng X, Mercer SE, Shah S, Ewton DZ, Friedman E. The cyclin-dependent kinase inhibitor p27Kip1 is stabilized in $\mathrm{G}(0)$ by Mirk/dyrk1B kinase. J Biol Chem. (2004) 279:22498-504. doi: 10.1074/jbc.M400479200

63. Poon RY, Toyoshima H, Hunter T. Redistribution of the CDK inhibitor p27 between different cyclin.CDK complexes in the mouse fibroblast cell cycle and in cells arrested with lovastatin or ultraviolet irradiation. Mol Biol Cell. (1995) 6:1197-213. doi: 10.1091/mbc.6.9.1197

64. García-Martín A, Ardura JA, Maycas M, Lozano D, López-Herradón A, Portal-Núñez $S$, et al. Functional roles of the nuclear localization signal of parathyroid hormone-related protein (PTHrP) in osteoblastic cells. $\mathrm{Mol}$ Endocrinol. (2014) 28:925-34. doi: 10.1210/me.2013-1225

65. Aarts MM, Rix A, Guo J, Bringhurst R, Henderson JE. The nucleolar targeting signal (NTS) of parathyroid hormone related protein mediates endocytosis and nucleolar translocation. J Bone Miner Res. (1999) 14:1493503. doi: 10.1359/jbmr.1999.14.9.1493

66. Kiefer P, Acland P, Pappin D, Peters G, Dickson C. Competition between nuclear localization and secretory signals determines the subcellular fate of a single CUG-initiated form of FGF3. EMBO J. (1994) 13:4126-36. doi: 10.1002/j.1460-2075.1994.tb06730.x

67. Nguyen M, He B, Karaplis A. Nuclear forms of parathyroid hormonerelated peptide are translated from non-AUG start sites downstream from the initiator methionine. Endocrinology. (2001) 142:694-703. doi: 10.1210/endo.142.2.7944

68. Li J, Karaplis AC, Huang DC, Siegel PM, Camirand A, Yang XF, et al. PTHrP drives breast tumor initiation, progression, and metastasis in mice and is a potential therapy target. J Clin Investig. (2011) 121:4655-69. doi: 10.1172/JCI46134

69. Tovar Sepulveda VA, Shen X, Falzon M. Intracrine PTHrP protects against serum starvation-induced apoptosis and regulates the cell cycle in MCF-7 breast cancer cells. Endocrinology. (2002) 143:596-606. doi: 10.1210/endo.143.2.8645

70. Gujral A, Burton DW, Terkeltaub R, Deftos LJ. Parathyroid hormone-related protein induces interleukin 8 production by prostate cancer cells via a novel intracrine mechanism not mediated by its classical nuclear localization sequence. Cancer Res. (2001) 61:2282-8.
71. Dougherty KM, Blomme EA, Koh AJ, Henderson JE, Pienta KJ, Rosol TJ, et al. Parathyroid hormone-related protein as a growth regulator of prostate carcinoma. Cancer Res. (1999) 59:6015-22.

72. Massfelder T, Lang H, Schordan E, Lindner V, Rothhut S, Welsch $\mathrm{S}$, et al. Parathyroid hormone-related protein is an essential growth factor for human clear cell renal carcinoma and a target for the von Hippel-Lindau tumor suppressor gene. Cancer Res. (2004) 64:180-8. doi: 10.1158/0008-5472.CAN-03-1968

73. Shen X, Mula RV, Evers BM, Falzon M. Increased cell survival, migration, invasion, and Akt expression in PTHrP-overexpressing LoVo colon cancer cell lines. Regul Pept. (2007) 141:61-72. doi: 10.1016/j.regpep.2006.12.017

74. Shen X, Falzon M. Parathyroid hormone-related protein upregulates integrin expression via an intracrine pathway in PC-3 prostate cancer cells. Regul Pept. (2003) 113:17-29. doi: 10.1016/S0167-0115(02)00293-8

75. Desgrosellier JS, Cheresh DA. Integrins in cancer: biological implications and therapeutic opportunities. Nat Rev Cancer. (2010) 10:9-22. doi: $10.1038 / \mathrm{nrc} 2748$

76. Hamidi H, Ivaska J. Every step of the way: integrins in cancer progression and metastasis. Nat Rev Cancer. (2018) 18:533-48. doi: 10.1038/s41568-018-0038-z

77. Fleming NI, Trivett MK, George J, Slavin JL, Murray WK, Moseley JM, et al. Parathyroid hormone-related protein protects against mammary tumor emergence and is associated with monocyte infiltration in ductal carcinoma in situ. Cancer Res. (2009) 69:7473. doi: 10.1158/0008-5472.CAN-09-0194

78. Hager JH, Hodgson JG, Fridlyand J, Hariono S, Gray JW, Hanahan D. Oncogene expression and genetic background influence the frequency of DNA copy number abnormalities in mouse pancreatic islet cell carcinomas. Cancer Res. (2004) 64:2406-10. doi: 10.1158/0008-5472.CAN-03-3522

79. Lifsted $\mathrm{T}$, Le Voyer $\mathrm{T}$, Williams $\mathrm{M}$, Muller $\mathrm{W}$, Klein-Szanto $\mathrm{A}$, Buetow $\mathrm{KH}$, et al. Identification of inbred mouse strains harboring genetic modifiers of mammary tumor age of onset and metastatic progression. Int $J$ Cancer. (1998) 77:640-4. doi: 10.1002/(SICI)1097-0215(19980812)77:4<640::AID-IJC26>3.0.CO;2-8

80. Supsavhad W, Dirksen WP, Martin CK, Rosol TJ. Animal models of head and neck squamous cell carcinoma. Vet J. (2016) 210:7-16. doi: 10.1016/j.tvjl.2015.11.006

81. Tannehill-Gregg SH, Levine AL, Rosol TJ. Feline head and neck squamous cell carcinoma: a natural model for the human disease and development of a mouse model. Vet Comp Oncol. (2006) 4:84-97. doi: 10.1111/j.1476-5810.2006.00096.x

82. Martin CK, Tannehill-Gregg SH, Wolfe TD, Rosol TJ. Bone-invasive oral squamous cell carcinoma in cats: pathology and expression of parathyroid hormone-related protein. Vet Pathol. (2011) 48:302-12. doi: $10.1177 / 0300985810384414$

83. Tannehill-Gregg S, Kergosien E, Rosol TJ. Feline head and neck squamous cell carcinoma cell line: characterization, production of parathyroid hormone-related protein, and regulation by transforming growth factor- $\beta$. In Vitro Cell Dev Biol Animal. (2001) 37:676-83. doi: 10.1290/1071-2690(2001)037<0676:FHANSC>2.0.CO;2

84. Lindemann RK, Ballschmieter P, Nordheim A, Dittmer J. Transforming growth factor beta regulates parathyroid hormone-related protein expression in MDA-MB-231 breast cancer cells through a novel Smad/Ets synergism. J Biol Chem. (2001) 276:46661-70. doi: 10.1074/jbc.M105816200

85. Al-Khan AA, Nimmo JS, Tayebi M, Ryan SD, Simcock JO, Tarzi R, et al. Parathyroid hormone receptor 1 (PTHR1) is a prognostic indicator in canine osteosarcoma. Sci Rep. (2020) 10:1564. doi: 10.1038/s41598-020-58524-3

86. Gröne A, Werkmeister JR, Steinmeyer CL, Capen CC, Rosol TJ. Parathyroid hormone-related protein in normal and neoplastic canine tissues: immunohistochemical localization and biochemical extraction. Vet Pathol. (1994) 31:308-15. doi: 10.1177/030098589403100303

87. Thomas RJ, Guise TA, Yin JJ, Elliott J, Horwood NJ, Martin TJ, et al. Breast cancer cells interact with osteoblasts to support osteoclast formation. Endocrinology. (1999) 140:4451-8. doi: 10.1210/endo.140.10.7037

88. Barkan D, Kleinman H, Simmons JL, Asmussen H, Kamaraju AK, Hoenorhoff MJ, et al. Inhibition of metastatic outgrowth from single dormant tumor cells by targeting the cytoskeleton. Cancer Res. (2008) 68:6241-50. doi: 10.1158/0008-5472.CAN-07-6849 
89. Wang H, Yu C, Gao X, Welte T, Muscarella AM, Tian L, et al. The osteogenic niche promotes early-stage bone colonization of disseminated breast cancer cells. Cancer Cell. (2015) 27:193-210. doi: 10.1016/j.ccell.2014.11.017

90. Ghajar CM, Peinado H, Mori H, Matei IR, Evason KJ, Brazier H, et al. The perivascular niche regulates breast tumour dormancy. Nat Cell Biol. (2013) 15:807-17. doi: 10.1038/ncb2767

91. Bragado P, Estrada Y, Parikh F, Krause S, Capobianco C, Farina HG, et al. TGF- $\beta 2$ dictates disseminated tumour cell fate in target organs through TGF- $\beta$-RIII and p38 $\alpha / \beta$ signalling. Nat Cell Biol. (2013) 15:1351-61. doi: $10.1038 /$ ncb2861

92. Kim RS, Avivar-Valderas A, Estrada Y, Bragado P, Sosa MS, AguirreGhiso JA, et al. Dormancy signatures and metastasis in estrogen receptor positive and negative breast cancer. PLoS ONE. (2012) 7:e35569. doi: 10.1371/journal.pone.0035569

93. Oki T, Nishimura K, Kitaura J, Togami K, Maehara A, Izawa K, et al. A novel cell-cycle-indicator, mVenus-p27K-, identifies quiescent cells and visualizes G0-G1 transition. Sci Rep. (2014) 4:4012. doi: 10.1038/srep04012

94. Johnson RW, Sun Y, Ho PWM, Chan ASM, Johnson JA, Pavlos NJ, et al. Parathyroid hormone-related protein negatively regulates tumor cell dormancy genes in a PTHR1/Cyclic AMP-independent manner. Front Endocrinol. (2018) 9:241. doi: 10.3389/fendo.2018.00241

95. Walia MK, Ho PM, Taylor S, Ng AJ, Gupte A, Chalk AM, et al. Activation of PTHrP-cAMP-CREB1 signaling following p53 loss is essential for osteosarcoma initiation and maintenance. eLife. (2016) 5:e13446. doi: 10.7554/eLife.13446

96. Barney LE, Hall CL, Schwartz AD, Parks AN, Sparages C, Galarza S, et al. Tumor cell-organized fibronectin maintenance of a dormant breast cancer population. Sci Adv. (2020) 6:eaaz4157. doi: 10.1126/sciadv.aaz4157

97. Parker AL, Cox TR. The role of the ECM in lung cancer dormancy and outgrowth. Front Oncol. (2020) 10:1766. doi: 10.3389/fonc.2020.01766

98. Winkler J, Abisoye-Ogunniyan A, Metcalf KJ, Werb Z. Concepts of extracellular matrix remodelling in tumour progression and metastasis. Nat Commun. (2020) 11:5120. doi: 10.1038/s41467-020-18794-x

99. Barkan D, Green JE, Chambers AF. Extracellular matrix: a gatekeeper in the transition from dormancy to metastatic growth. Eur J Cancer. (2010) 46:1181-8. doi: 10.1016/j.ejca.2010.02.027

100. Aguirre Ghiso JA, Kovalski K, Ossowski L. Tumor dormancy induced by downregulation of urokinase receptor in human carcinoma involves integrin and MAPK signaling. J Cell Biol. (1999) 147:89-104. doi: $10.1083 /$ jcb.147.1.89

101. Aguirre-Ghiso JA, Estrada Y, Liu D, Ossowski L. ERK(MAPK) activity as a determinant of tumor growth and dormancy; regulation by p38(SAPK). Cancer Res. (2003) 63:1684-95. doi: 10.1016/j.urolonc.2003.12.012

102. Aguirre-Ghiso JA, Liu D, Mignatti A, Kovalski K, Ossowski L. Urokinase receptor and fibronectin regulate the ERK(MAPK) to p38(MAPK) activity ratios that determine carcinoma cell proliferation or dormancy in vivo. Mol Biol Cell. (2001) 12:863-79. doi: 10.1091/mbc.12.4.863

103. Anderson JA, Grabowska AM, Watson SA. PTHrP increases transcriptional activity of the integrin subunit alpha5. Br J Cancer. (2007) 96:1394-403. doi: $10.1038 /$ sj.bjc. 6603720

104. Deftos LJ, Barken I, Burton DW, Hoffman RM, Geller J. Direct evidence that PTHrP expression promotes prostate cancer progression in bone. Biochem Biophys Res Commun. (2005) 327:468-72. doi: 10.1016/j.bbrc.2004.11.162

105. Dougherty M K, Blomme EAG, Koh AJ, Henderson JE, Pienta KJ, Rosol TJ, et al. Parathyroid hormone-related protein as a growth regulator of prostate carcinoma. Cancer Res. (1999) 59:6015.

106. Mak IWY, Cowan RW, Turcotte RE, Singh G, Ghert M. PTHrP induces autocrine/paracrine proliferation of bone tumor cells through inhibition of apoptosis. PLoS ONE. (2011) 6:e19975. doi: 10.1371/journal.pone.0019975

107. Okoumassoun LE, Russo C, Denizeau F, Averill-Bates D, Henderson JE. Parathyroid hormone-related protein (PTHrP) inhibits mitochondrialdependent apoptosis through CK2. J Cell Physiol. (2007) 212:591-9. doi: $10.1002 /$ jcp. 21055

108. Hastings RH, Burton DW, Quintana RA, Biederman E, Gujral A, Deftos LJ. Parathyroid hormone-related protein regulates the growth of orthotopic human lung tumors in athymic mice. Cancer. (2001) 92:1402-10. doi: 10.1002/1097-0142(20010915)92:6<1402::AIDCNCR1463>3.0.CO;2-A
109. Hastings RH, Montgrain PR, Quintana R, Rascon Y, Deftos LJ, Healy E. Cell cycle actions of parathyroid hormone-related protein in non-small cell lung carcinoma. Am J Physiol Lung Cell Mol Physiol. (2009) 297:L578-85. doi: 10.1152/ajplung.90560.2008

110. Mattaj IW, Englmeier L. Nucleocytoplasmic transport: the soluble phase. Annu Rev Biochem. (1998) 67:265-306. doi: 10.1146/annurev.biochem.67.1.265

111. Folkman J. Tumor angiogenesis: therapeutic implications. N Engl J Med. (1971) 285:1182-6. doi: 10.1056/NEJM197111182852108

112. Chow DC, Wenning LA, Miller WM, Papoutsakis ET. Modeling pO(2) distributions in the bone marrow hematopoietic compartment. I. Krogh's model. Biophys J. (2001) 81:675-84. doi: 10.1016/S0006-3495(01)75732-3

113. Spencer JA, Ferraro F, Roussakis E, Klein A, Wu J, Runnels JM, et al. Direct measurement of local oxygen concentration in the bone marrow of live animals. Nature. (2014) 508:269-73. doi: 10.1038/nature13034

114. Höckel M, Vaupel P. Tumor hypoxia: definitions and current clinical, biologic, molecular aspects. J Natl Cancer Inst. (2001) 93:266-76. doi: 10.1093/jnci/93.4.266

115. Weis SM, Cheresh DA. Tumor angiogenesis: molecular pathways and therapeutic targets. Nat Med. (2011) 17:1359-70. doi: 10.1038/nm.2537

116. Hanahan D, Folkman J. Patterns and emerging mechanisms of the angiogenic switch during tumorigenesis. Cell. (1996) 86:353-64. doi: 10.1016/S0092-8674(00)80108-7

117. Bakre MM, Zhu Y, Yin H, Burton DW, Terkeltaub R, Deftos LJ, et al. Parathyroid hormone-related peptide is a naturally occurring, protein kinase A-dependent angiogenesis inhibitor. Nat Med. (2002) 8:995-1003. doi: $10.1038 / \mathrm{nm} 753$

118. Calvo N, Carriere P, Martín MJ, Gigola G, Gentili C. PTHrP treatment of colon cancer cells promotes tumor associated-angiogenesis by the effect of VEGF. Mol Cell Endocrinol. (2019) 483:50-63. doi: 10.1016/j.mce.2019.01.005

119. Isowa S, Shimo T, Ibaragi S, Kurio N, Okui T, Matsubara K, et al. PTHrP regulates angiogenesis and bone resorption via VEGF expression. Anticancer Res. (2010) 30:2755-67.

120. Akino K, Ohtsuru A, Kanda K, Yasuda A, Yamamoto T, Akino Y, et al. Parathyroid hormone-related peptide is a potent tumor angiogenic factor. Endocrinology. (2000) 141:4313-6. doi: 10.1210/endo.141.11.7875

121. Pelosi M, Lazzarano S, Thoms BL, Murphy CL. Parathyroid hormone-related protein is induced by hypoxia and promotes expression of the differentiated phenotype of human articular chondrocytes. Clin Sci. (2013) 125:461-70. doi: 10.1042/CS20120610

122. Manisterski M, Golan M, Amir S, Weisman Y, Mabjeesh NJ. Hypoxia induces PTHrP gene transcription in human cancer cells through the HIF-2alpha. Cell Cycle. (2010) 9:3723-9. doi: 10.4161/cc.9.18.12931

123. Butturini E, Carcereri de Prati A, Boriero D, Mariotto S. Tumor dormancy and interplay with hypoxic tumor microenvironment. Int J Mol Sci. (2019) 20:4305. doi: 10.3390/ijms20174305

124. Endo H, Okuyama H, Ohue M, Inoue M. Dormancy of cancer cells with suppression of AKT activity contributes to survival in chronic hypoxia. PLoS ONE. (2014) 9:e98858. doi: 10.1371/journal.pone.0098858

125. Ochsenbein AF. Principles of tumor immunosurveillance and implications for immunotherapy. Cancer Gene Ther. (2002) 9:1043-55. doi: 10.1038/sj.cgt.7700540

126. Borst J, Ahrends T, Babała N, Melief CJM, Kastenmüller W. CD4(+) T cell help in cancer immunology and immunotherapy. Nat Rev Immunol. (2018) 18:635-47. doi: 10.1038/s41577-018-0044-0

127. Feuerer M, Rocha M, Bai L, Umansky V, Solomayer EF, Bastert G, et al. Enrichment of memory $T$ cells and other profound immunological changes in the bone marrow from untreated breast cancer patients. Int J Cancer. (2001) 92:96-105. doi: 10.1002/1097-0215(200102)9999:9999<::AID-IJC1152>3.0.CO;2-Q

128. Farrar JD, Katz KH, Windsor J, Thrush G, Scheuermann RH, Uhr JW, et al. Cancer dormancy. VII. A regulatory role for CD8 $+\mathrm{T}$ cells and IFN-gamma in establishing and maintaining the tumor-dormant state. $J$ Immunol. (1999) 162:2842-9.

129. Koebel CM, Vermi W, Swann JB, Zerafa N, Rodig SJ, Old LJ, et al. Adaptive immunity maintains occult cancer in an equilibrium state. Nature. (2007) 450:903-7. doi: 10.1038/nature06309 
130. Nair VR, Malladi S. Mouse models to study natural killer cell-mediated immunosurveillance and metastatic latency. Methods Mol Biol. (2019) 1884:141-50. doi: 10.1007/978-1-4939-8885-3_9

131. Saudemont A, Jouy N, Hetuin D, Quesnel B. NK cells that are activated by CXCL10 can kill dormant tumor cells that resist CTL-mediated lysis and can express B7-H1 that stimulates T cells. Blood. (2005) 105:2428-35. doi: 10.1182/blood-2004-09-3458

132. Deng L, Zhang H, Luan Y, Zhang J, Xing Q, Dong S, et al. Accumulation of foxp3 $+\mathrm{T}$ regulatory cells in draining lymph nodes correlates with disease progression and immune suppression in colorectal cancer patients. Clin Cancer Res. (2010) 16:4105-12. doi: 10.1158/1078-0432.CCR-10-1073

133. Martinez LM, Robila V, Clark NM, Du W, Idowu MO, Rutkowski MR, et al. Regulatory T cells control the switch from in situ to invasive breast cancer. Front Immunol. (2019) 10:1942. doi: 10.3389/fimmu.2019.01942

134. Di Mitri D, Toso A, Chen JJ, Sarti M, Pinton S, Jost TR, et al. Tumourinfiltrating Gr-1+ myeloid cells antagonize senescence in cancer. Nature. (2014) 515:134-7. doi: 10.1038/nature13638

135. Kitamura T, Qian BZ, Pollard JW. Immune cell promotion of metastasis. Nat Rev Immunol. (2015) 15:73-86. doi: 10.1038/nri3789

136. Younos I, Donkor M, Hoke T, Dafferner A, Samson H, Westphal $\mathrm{S}$, et al. Tumor- and organ-dependent infiltration by myeloidderived suppressor cells. Int Immunopharmacol. (2011) 11:816-26. doi: 10.1016/j.intimp.2011.02.021

137. Park SI, Lee C, Sadler WD, Koh AJ, Jones J, Seo JW, et al. Parathyroid hormone-related protein drives a $\mathrm{CD} 11 \mathrm{~b}+\mathrm{Gr} 1+$ cell-mediated positive feedback loop to support prostate cancer growth. Cancer Res. (2013) 73:6574-83. doi: 10.1158/0008-5472.CAN-12-4692

138. Yang L, Huang J, Ren X, Gorska AE, Chytil A, Aakre M, et al. Abrogation of TGF beta signaling in mammary carcinomas recruits Gr-1+CD11b+ myeloid cells that promote metastasis. Cancer Cell. (2008) 13:23-35. doi: 10.1016/j.ccr.2007.12.004

139. Danilin S, Merkel AR, Johnson JR, Johnson RW, Edwards JR, Sterling JA. Myeloid-derived suppressor cells expand during breast cancer progression and promote tumor-induced bone destruction. Oncoimmunology. (2012) 1:1484-94. doi: 10.4161/onci.21990

140. Marvel D, Gabrilovich DI. Myeloid-derived suppressor cells in the tumor microenvironment: expect the unexpected. J Clin Invest. (2015) 125:3356-64. doi: 10.1172/JCI80005

141. Ostrand-Rosenberg S, Fenselau C. Myeloid-derived suppressor cells: immune-suppressive cells that impair antitumor immunity and are sculpted by their environment. J Immunol. (2018) 200:422-31. doi: 10.4049/jimmunol.1701019

142. Henderson MA, Danks JA, Moseley JM, Slavin JL, Harris TL, McKinlay MR, et al. Parathyroid hormone-related protein production by breast cancers, improved survival, and reduced bone metastases. J Natl Cancer Inst. (2001) 93:234-7. doi: 10.1093/jnci/93.3.234

143. Tran TH, Utama FE, Sato T, Peck AR, Langenheim JF, Udhane SS, et al. Loss of nuclear localized parathyroid hormone-related protein in primary breast cancer predicts poor clinical outcome and correlates with suppressed Stat5 signaling. Clin Cancer Res. (2018). 24:6355-66. doi: 10.1158/1078-0432.CCR-17-3280

144. Peck AR, Witkiewicz AK, Liu C, Klimowicz AC, Stringer GA, Pequignot E, et al. Low levels of Stat5a protein in breast cancer are associated with tumor progression and unfavorable clinical outcomes. Breast Cancer Res. (2012) 14:R130. doi: 10.1186/bcr3328

145. Peck AR, Witkiewicz AK, Liu C, Stringer GA, Klimowicz AC, Pequignot E, et al. Loss of nuclear localized and tyrosine phosphorylated Stat5 in breast cancer predicts poor clinical outcome and increased risk of antiestrogen therapy failure. J Clin Oncol. (2011) 29:2448-58. doi: 10.1158/1538-7445.AM2011-2277

146. Montgrain PR, Deftos LJ, Arenberg D, Tipps A, Quintana R, Carskadon $S$, et al. Prognostic implications of parathyroid hormone-related protein in males and females with non-small-cell lung cancer. Clin Lung Cancer. (2011) 12:197-205. doi: 10.1016/j.cllc.2011.03.018

147. Funk JL, Wei H. Regulation of parathyroid hormone-related protein expression in MCF-7 breast carcinoma cells by estrogen and antiestrogens. Biochem Biophys Res Commun. (1998) 251:849-54. doi: 10.1006/bbrc. 1998.9568
148. Iwamura $\mathrm{M}$, $\mathrm{Wu} \mathrm{W}$, Muramoto $\mathrm{M}$, Ohori $\mathrm{M}$, Egawa S, Uchida $\mathrm{T}$, et al. Parathyroid hormone-related protein is an independent prognostic factor for renal cell carcinoma. Cancer. (1999) 86:102834. doi: 10.1002/(SICI)1097-0142(19990915)86:6<1028::AIDCNCR19>3.0.CO;2-G

149. Ghoussaini M, Fletcher O, Michailidou K, Turnbull C, Schmidt MK, Dicks $\mathrm{E}$, et al. Genome-wide association analysis identifies three new breast cancer susceptibility loci. Nat Genet. (2012) 44:312-8. doi: 10.1038/ng.1049

150. Linforth R, Anderson N, Hoey R, Nolan T, Downey S, Brady G, et al. Coexpression of parathyroid hormone related protein and its receptor in early breast cancer predicts poor patient survival. Clin Cancer Res. (2002) 8:3172-7.

151. Southby J, Kissin MW, Danks JA, Hayman JA, Moseley JM, Henderson $\mathrm{MA}$, et al. Immunohistochemical localization of parathyroid hormonerelated protein in human breast cancer. Cancer Res. (1990) 50:7710-6. doi: 10.1016/S0031-3025(16)36341-3

152. Yoshida A, Nakamura Y, Shimizu A, Harada M, Kameda Y, Nagano A, et al. Significance of the parathyroid hormone-related protein expression in breast carcinoma. Breast Cancer. (2000) 7:215-20. doi: 10.1007/BF02967463

153. Assaker G, Camirand A, Abdulkarim B, Omeroglu A, Deschenes J, Joseph K, et al. A biomarker for CNS metastasis in triple-negative breast cancer and selection for adjuvant chemotherapy in node-negative disease. JNCI Cancer Spectrum. (2019) 4:pkz063. doi: 10.1093/jncics/pkz063

154. Asadi F, Farraj M, Sharifi R, Malakouti S, Antar S, Kukreja S. Enhanced expression of parathyroid hormone-related protein in prostate cancer as compared with benign prostatic hyperplasia. Hum Pathol. (1996) 27:131923. doi: 10.1016/S0046-8177(96)90344-5

155. Bryden AA, Islam S, Freemont AJ, Shanks JH, George NJ, Clarke NW. Parathyroid hormone-related peptide: expression in prostate cancer bone metastases. Prostate Cancer Prostatic Dis. (2002) 5:59-62. doi: 10.1038/sj.pcan.4500553

156. Monego G, Lauriola L, Ramella S, D’Angelillo RM, Lanza P, Granone P, et al. Parathyroid hormone-related peptide and parathyroid hormone-related peptide receptor type 1 expression in human lung adenocarcinoma. Chest. (2010) 137:898-908. doi: 10.1378/chest.09-1358

157. Burtis WJ, Fodero JP, Gaich G, Debeyssey M, Stewart AF. Preliminary characterization of circulating amino- and carboxy-terminal fragments of parathyroid hormone-related peptide in humoral hypercalcemia of malignancy. J Clin Endocrinol Metab. (1992) 75:1110-4. doi: 10.1210/jcem.75.4.1400879

158. Imamura H, Sato K, Shizume K, Satoh T, Kasono K, Ozawa M, et al. Urinary excretion of parathyroid hormone-related protein fragments in patients with humoral hypercalcemia of malignancy and hypercalcemic tumor-bearing nude mice. J Bone Mineral Res. (1991) 6:77-84. doi: $10.1002 / \mathrm{jbmr} .5650060113$

159. Gallwitz WE, Guise TA, Mundy GR. Guanosine nucleotides inhibit different syndromes of PTHrP excess caused by human cancers in vivo. J Clin Investig. (2002) 110:1559-72. doi: 10.1172/JCI0211936

160. Guise TA, Yin JJ, Taylor SD, Kumagai Y, Dallas M, Boyce BF, et al. Evidence for a causal role of parathyroid hormone-related protein in the pathogenesis of human breast cancer-mediated osteolysis. J Clin Invest. (1996) 98:1544-9. doi: 10.1172/JCI118947

161. Saito H, Tsunenari T, Onuma E, Sato K, Ogata E, Yamada-Okabe H. Humanized monoclonal antibody against parathyroid hormone-related protein suppresses osteolytic bone metastasis of human breast cancer cells derived from MDA-MB-231. Anticancer Res. (2005) 25(6b):3817-23. doi: 10.1002/(sici)1097-0142(19971015)80:8+<1572::aid-cncr7>3.3.co;2-d

162. Martin TJ, Johnson RW. Multiple actions of parathyroid hormonerelated protein in breast cancer bone metastasis. Br J Pharmacol. (2019). doi: 10.1111/bph.14709

163. Clevers H. Wnt/beta-catenin signaling in development and disease. Cell. (2006) 127:469-80. doi: 10.1016/j.cell.2006.10.018

164. Glass DA 2nd, Bialek P, Ahn JD, Starbuck M, Patel MS, Clevers H, et al. Canonical Wnt signaling in differentiated osteoblasts controls osteoclast differentiation. Dev Cell. (2005) 8:751-64. doi: 10.1016/j.devcel.2005. 02.017

165. Golovchenko S, Hattori T, Hartmann C, Gebhardt M, Gebhard S, Hess $A$, et al. Deletion of beta catenin in hypertrophic growth plate 
chondrocytes impairs trabecular bone formation. Bone. (2013) 55:102-12. doi: 10.1016/j.bone.2013.03.019

166. Cheng $\mathrm{X}, \mathrm{Xu} \mathrm{X}$, Chen $\mathrm{D}$, Zhao F, Wang W. Therapeutic potential of targeting the Wnt/ $\beta$-catenin signaling pathway in colorectal cancer. Biomed Pharmacother. (2019) 110:473-81. doi: 10.1016/j.biopha.2018.11.082

167. Tam BY, Chiu K, Chung H, Bossard C, Nguyen JD, Creger E, et al. The CLK inhibitor SM08502 induces anti-tumor activity and reduces Wnt pathway gene expression in gastrointestinal cancer models. Cancer Lett. (2020) 473:186-97. doi: 10.1016/j.canlet.2019.09.009

168. Jung YS, Jun S, Kim MJ, Lee SH, Suh HN, Lien EM, et al. TMEM9 promotes intestinal tumorigenesis through vacuolar-ATPase-activated Wnt/ $\beta$-catenin signalling. Nat Cell Biol. (2018) 20:1421-33. doi: 10.1038/s41556-018-0219-8

169. Jung Y-S, Park J-I. Wnt signaling in cancer: therapeutic targeting of Wnt signaling beyond $\beta$-catenin and the destruction complex. Exp Mol Med. (2020) 52:183-91. doi: 10.1038/s12276-020-0380-6

170. Liu J, Pan S, Hsieh MH, Ng N, Sun F, Wang T, et al. Targeting Wnt-driven cancer through the inhibition of porcupine by LGK974. Proc Natl Acad Sci USA. (2013) 110:20224. doi: 10.1073/pnas.1314239110

171. Madan B, Ke Z, Harmston N, Ho SY, Frois AO, Alam J, et al. Wnt addiction of genetically defined cancers reversed by PORCN inhibition. Oncogene. (2016) 35:2197-207. doi: 10.1038/onc.2015.280

172. Johnson RW, Nguyen MP, Padalecki SS, Grubbs BG, Merkel AR, Oyajobi $\mathrm{BO}$, et al. TGF-beta promotion of Gli2-induced expression of parathyroid hormone-related protein, an important osteolytic factor in bone metastasis, is independent of canonical Hedgehog signaling. Cancer Res. (2011) 71:82231. doi: 10.1158/0008-5472.CAN-10-2993

173. Sterling JA, Oyajobi BO, Grubbs B, Padalecki SS, Munoz SA, Gupta A, et al. The hedgehog signaling molecule Gli2 induces parathyroid hormone-related peptide expression and osteolysis in metastatic human breast cancer cells. Cancer Res. (2006) 66:7548. doi: 10.1158/0008-5472.CAN-060452

174. Ally MS, Ransohoff K, Sarin K, Atwood SX, Rezaee M, Bailey-Healy I, et al. Effects of combined treatment with arsenic trioxide and itraconazole in patients with refractory metastatic basal cell carcinoma. JAMA Dermatol. (2016) 152:452-6. doi: 10.1001/jamadermatol.2015. 5473

175. Furugaki K, Moriya Y, Iwai T, Yorozu K, Yanagisawa M, Kondoh K, et al. Erlotinib inhibits osteolytic bone invasion of human non-small-cell lung cancer cell line NCI-H292. Clin Exp Metastasis. (2011) 28:649-59. doi: 10.1007/s10585-011-9398-4

176. Lorch G, Gilmore JL, Koltz PF, Gonterman RM, Laughner R, Lewis $\mathrm{DA}$, et al. Inhibition of epidermal growth factor receptor signalling reduces hypercalcaemia induced by human lung squamous-cell carcinoma in athymic mice. $\mathrm{Br} J$ Cancer. (2007) 97:183-93. doi: 10.1038/sj.bjc. 6603828

Conflict of Interest: The authors declare that the research was conducted in the absence of any commercial or financial relationships that could be construed as a potential conflict of interest.

Copyright $\odot 2021$ Edwards and Johnson. This is an open-access article distributed under the terms of the Creative Commons Attribution License (CC BY). The use, distribution or reproduction in other forums is permitted, provided the original author(s) and the copyright owner(s) are credited and that the original publication in this journal is cited, in accordance with accepted academic practice. No use, distribution or reproduction is permitted which does not comply with these terms. 